\title{
Osmanlı Döneminde Farsçadan Türkçeye Tercüme Edilen Bazı Mühim Tasavvufí Eserler
}

\author{
Necdet TOSUN*
}

$\ddot{O} z$

Osmanlı döneminde birçok eser Farsçadan Türkçeye tercüme edilmiştir. Bu eserlerden önemli bir kısmı da tasavvuf konusundadır. Tercümeye konu olan Farsça eserlerden bazıları Anadolu (Türkiye) ve Mâverâünnehr (Özbekistan) gibi ana dilin Türkçe olduğu bölgelerde yazılmış, bazıları ise İran, Afganistan, Tacikistan ve Hindistan gibi ülkelerde kaleme alınmıştır. Bu Farsça eserler İslam dünyasında veya yazıldığ coğrafyada beğenilip ilgi görmüş ve bu sebeple Anadolu' da Türkçeye tercüme edilmiştir. Bu tercümelerden bazıları Osmanlı döneminde matbaada basılmış ise de, çoğunluğu yazma olarak kütüphanelerde durmaktadır. Bu tercüme eserlerden mühim olanları ve mütercimleri hakkında bu makalede bilgi verilmektedir.

İran'da yazılan Bostan, Gülistân, Mantıku 't-tayr ve Pendnâme-i Attâr gibi eserler üzerine Osmanlı döneminde Türkçe birçok şerh yazılmıştır. Hattâ bu Türkçe şerhlerden bazıları çok değerli bulunmuş ve Farsçaya çevrilip yayınlanmıştır. Yani Farsçadan Türkçeye çevrilip şerh edilen eserler tekrar Farsçaya çevrilip asıl vatanında okunur hâle gelmiştir. Bu sayede ülkeler arasında kültür paylaşımı olmuş, İslam kültürüne önemli katkılar sağlanmıştır.

Bu makâlede, Osmanlı döneminde Farsçadan Türkçeye tercüme edilen tasavvufî eserlerin önde gelenleri toplanıp bir araya getirilmiş, böylece konuya ilgi duyan kişilere ve araştırmacılara önemli bir kolaylık sağlanmıştır. Ayrıca makâlede, a) Osmanlı döneminde hangi tasavvufî eserlerin Türkçeye tercüme edildiği, b) Tercümelerin hangi coğrafyalardan (İran, Orta Asya, Hindistan vs.) yapıldığı, c) 15. Yüzyıldan sonra tercümeye konu olan eserlerin İran'dan ziyâde Orta Asya ve Hindistan'a kaymasının sebepleri gibi problemlerin cevabı aranmıştır.

Anahtar Kelimeler: Tasavvuf, Osmanl, Farsça, Tercüme, Kitap.

\footnotetext{
* Prof. Dr. Marmara Üniversitesi İlahiyat Fakültesi Tasavvuf Anabilim Dalı, İstanbul, Türkiye Elmek: ntosun@hotmail.com https://orcid.org/0000-0001-7618-916X
} 


\title{
Some Important Sufi Works Translated from Persian into Turkish in the Ottoman Period
}

\begin{abstract}
Many scholarly works were translated from Persian into Ottoman Turkish during the Ottoman period. A considerable portion of those books was on Sufism. Some of these Persian works were written in regions where the native language was Turkish such as Asia Minor (Turkey) and Transoxiana (Uzbekistan), while others were written in other countries such as Persia, Afghanistan, Tajikistan and India. These Persian works were appreciated and attracted attention in the Muslim world as well as in the lands where they had been written and thus they were translated into Turkish in Asia Minor. Even though some of these translations were published during the Ottoman period, most of them are maintained in the libraries as manuscripts. In this article, information will be given about the important ones of these translated works and their authors.

Many Turkish commentaries were written during the Ottoman Period on Sufi books such as Bostan, Gulistan, Mantıq al-tayr and Pand-i Attar which were written in Persia (Iran). Some of these Turkish commentaries were regarded so valuable that they were later translated into Persian and published. In other words, books which had been translated into Ottoman Turkish and commented upon were later re-translated into Persian and made available to the readers in their own land. In this way, they helped cultural exchange between countries and made significant contributions to Muslim culture.

In this article, some of the important Sufi works translated from Persian to Turkish during the Ottoman Period have been gathered. Thus, it aims to help the researchers and those who are interested in the subject. Moreover, the article seeks to answer certain questions such as, a) Which Sufi works were translated into Turkish during the Ottoman period, b) Where (Persia, Central Asia, India etc.) were these translations done? c) What were the reasons for the change of center of the works in question from Persia to Central Asia and India after the 15th century?
\end{abstract}

Keywords: Sufism, Ottoman, Persian, Translation, Book. 


\section{Extended Summary}

During the ages in which there were no instruments for visual and oral communication such as TVs, phones, and internet, books were the main means of transmitting knowledge, science and cultures from one country or continent to the others. Throughout the pre-printing period of human history, books written in one region would be duplicated by hand and sold in bookstores or given as gifts to those who were interested in them.

Those would also be read and spread in other countries just as they were benefited by the book lovers. The seekers of knowledge who visited other countries to get education, travelling dervishes, tradesmen, and pilgrims would take the books to their home countries. In this way, for example a book which had been written in the farthest corner of India could reach at Asia Minor (Turkey) or even at the Balkans and become a means of cultural communication.

Many original scholarly works were written and translated in Asia Minor during the Ottoman period. In addition to the books written in Arabic, there also were many more books translated from Persian. It looks like majority of those translations were about Sufism and Islamic ethics. The original copies of those books had been written in various countries, namely Persia, India, Afghanistan, and Transoxiana (Uzbekistan). Moreover, some Persian books written in Asia Minor were also translated into Turkish.

When the translations from Persian to Turkish are chronologically examined, it can be seen that a 5th / 11th century scholar Abdullah Ansari Harawi's two works were partially translated from Persian to Turkish in the 17th and 19th centuries. It looks like Imam al-Ghazali's Kimya-yi Sa'adah became chronologically the next book translated into Turkish for a couple of times. Fariduddin Attar's several books were also rendered into Turkish during the Ottoman period and Turkish commentaries were also written about some of them. Sharh-i Mantiq al-Tayr written by Sham'î Sham'ullah Efendi (d. 1011/1602?), a 16th century scholar who lived in Istanbul, is the earliest and only known Turkish classical gloss on Attar's Mantiq al-Tayr. It is worth to be translated into Persian. 
Mawlana Jalaluddin Rumi's famous Persian book titled Mathnawi-yi Ma'nawi was translated into Turkish and glossed for a couple of times during the Ottoman period. Its most famous commentary belongs to Isma'il Rusûhî Ankaravi (d.1041/1631). This commentary which was published during the Ottoman period has not been transliterated into modern Turkish script yet. However, it was translated from Persian to Turkish by Ismet Settarzade with the title Sharh-i Kabîr-i Anqaravî bar Mathnawî-yi Ma'nawî-yi Mawlavî and published in Tehran in 1970.

The Persian book titled Manâqib-i Shaykh Awhaduddin Kirmânî was published by Bedîuzzamân Furûzânfer in Tehran in 1969 and its author was stated as unknown. However, Muhyiddin Gelibolî who translated it into Turkish during the Ottoman period recorded that its author was Shaykh Sa'deddin, one of the prominent disciples of Awhaduddin Kirmânî. Since Shaykh Sa'deddin was a disciple of Awhaduddin, he must have lived in the 7th century hijrah. This should be recorded as new information.

Sa'di Shirazi's books titled Bostan and Gulistan were translated into Turkish for a couple of times during the Ottoman period. Two Turkish commentaries written by Sûdî Bosnevi, a 16th century Bosnian scholar, on Bostan and Gulistan were translated into Persian and published in the 20th century. Even though Sûdî's commentaries were published during the Ottoman period, there are few people who can read those old editions.

Even though many classical books on Sufism written until 9th / 15th century were translated into Ottoman Turkish, the translation changed their direction after that century. When we examine the translations done after the 9th century hijrah, we see that they were mostly the books of the adherents of Naqshbandiyya Sufi order emerged in Central Asia. This translation movement which began with Risala-i Qudsiyya and Fasl al-Khitab books by Muhammad Parsa al-Bukhari, one of the disciples of Bahauddin Naqshband continued by translating many other Naqshbandi authors' Persian books into Turkish. After 11th / 17th century when the Naqshbandiyya Sufi order spread in India through its Mujaddidiyya branch, the books of Naqshbandi Sufi masters living in India started to be translated into Turkish. In other words, the translations from Per- 
sian to Turkish between 15th and 19th centuries were the books of Naqshbandi Sufis who lived in Central Asia, Afghanistan and India.

In other words, even though the Sufi books written between 11th and 15th centuries in Persia (Iran) were translated into Turkish in different periods, those that were written and translated into Turkish between 15th and 19th centuries were usually the works of the followers of Naqshbandiyya Sufi Order. The only exception of this is the Turkish translations of the Indian Chishti Order master Imdâdullah Thânawi's books titled Diyâ al-Qulûb and Risâla-i Wahdat al-Wujûd. If the fact that Imdâdullah Chishti was also a Sufi master authorized by Naqshbandiyya Order is taken into account, this may not be regarded as an exception. The Persian books written in Persia after the 15 th century did not attract so much attention and deemed worthy to be translated.

After the 20th century, the movement was reversed and books written in Turkish were translated into Persian. The Turkish commentaries of Mathnawi, Bostan and Gulistan written in Turkish during the Ottoman Period were translated into Persian and presented to the readers' benefit even before they have not been transliterated into modern Turkish script, yet. However, it should still be mentioned that when compared, there is a big difference between the number of books translated from Persian to Turkish and the books translated from Turkish to Persian. The number of books translated from Turkish into Persian is very low and there were almost none before the 20th century.

In this article, some of the important Sufi works translated from Persian to Turkish during the Ottoman Period have been gathered. Thus, it aims to help the researchers and those who are interested in the subject. Moreover, the article seeks to answer certain questions such as,

a) Which Sufi works were translated into Turkish during the Ottoman Period,

b) Where (Persia, Central Asia, India etc.) were these translations done?

c) What were the reasons for the change of center of the works in question from Persia to Central Asia and India after the 15th century? 



\section{Giriş}

Telefon, televizyon ve internet gibi sesli ve görüntülü iletişim araçlar1nın bulunmadığ 1 dönemlerde asırlar boyu "kitaplar", ilim, düşünce ve kültürleri ülkeler ve kıtalar ötesine taşıyan en önemli araç olmuştur. Bir bölgede yazılan kitaplar, matbaanın da olmadığı dönemlerde el ile yazılarak çoğaltılır ve kitap dükkânlarında, sahaflarda satılır ya da ilgilenen kişilere hediye edilirdi. Bu kitaplar, kitapseverler arasında okunup istifade edildiği gibi başka ülkelere de yayılırdı. Eğitim almak için başka ülkelere giden ilim talebeleri, seyyah dervişler, tüccarlar, hacca veya umreye gidenler yazma eserleri kendi ülkelerine taşırlardı. Böylece Hindistan'ın ücra bir köşesinde yazılan bir eser Anadolu'ya (Türkiye'ye), hattâ Balkanlar'a kadar ulaşır ve İslam dünyasında kültürel iletişime vesile olurdu.

Osmanlı döneminde Anadolu'da telif ve tercüme birçok eser kaleme alınmıştı. Arapça'dan tercüme edilen eserlerin yanısıra, Farsçadan Tercüme edilen çok sayıda eser olmuştur. Farsçadan Türkçeye tercüme edilen eserlerin çoğunlukla tasavvuf ve ahlâk konusundaki eserler olduğu görülmektedir. Bu eserlerin Farsça asıllarının yazıldığı bölgeler şunlardı: İran, Hindistan, Afganistan ve Mâverâünnehr (Özbekistan). Ayrıca Anadolu'da yazılan bazı Farsça eserler de yine Anadolu'da Türkçeye tercüme edilmişti.

Osmanlı döneminde Farsçadan Türkçeye tercüme edilen eserlere tarihî sıra ile bakıldığında, hicrî 5. (miladî 11.) asırda yaşayan Abdullah Ensârî Herevî’nin Farsça iki eserinin 17. ve 19. Yüzyıllarda kısmen Türkçeye tercüme edildiği görülmektedir. Ardından İmâm-1 Gazâlî’nin Kîmyâ-yı Sa âdet isimli eserini birkaç defa Türkçeye tercüme edilmiştir. Ferîdüddin Attâr'ın birçok eseri Osmanlı döneminde Türkçeye tercüme edilmiş, bazı eserlerine Türkçe şerh de yazılmıştır. 16. yüzyılda İstanbul'da yaşayan Şem'î Şem'ullah Efendi (ö. 1011/1602 ?) tarafindan Türkçe olarak yazılan Şerh-i Mantıku't-tayr isimli eseri, Mantıku 't-tayr'in bilinen ilk ve tek klasik şerhidir. Farsçaya tercüme edilmeye de lâyıktır.

Mevlânâ Celâleddin Rûmî’nin Mesnevî-yi Ma'nevî isimli meşhur Farsça eseri Osmanlı döneminde Türkçeye birkaç defa tercüme ve şerh edilmiştir. En meşhur Türkçe şerhi İsmâil Rusûhî Ankaravî’ye (ö. 1041/1631) aittir. Osmanlı döne- 
minde yayınlanmış olan bu şerh, Türkiye'de yeni harflere henüz çevrilmemiştir. Ancak İsmet Settârzâde tarafindan Şerh- Kebîr-i Ankaravî ber Mesnevî-yi Ma’nevî-yi Mevlevî adiyla Türkçeden Farsçaya çevrilmiş ve 1970'te Tahran'da neşredilmiştir.

Menâkıb-ı Şeyh Evhadüddin Kirmânî isimli Farsça eser Bedîuzzamân Fürûzânfer tarafindan Tahran'da 1969'da neşredilmiş ve müellifi meçhul olarak kaydedilmiş idi. Ancak Bu eseri Osmanlı döneminde Türkçeye tercüme eden Muhyiddin Gelibolî, eserin Farsça aslını yazan kişinin, Evhadüddin Kirmânî’nin mürid ve halifelerinden Şeyh Sa'deddin olduğunu kaydetmiştir. Bu zât, Evhadüddin'in müridi olduğuna göre hicrî 7 . Asırda yaşamış olmalıdır. Bu da yeni bir bilgi olarak kayıtlara geçmelidir.

Sa'dî Şî̀âzî'nin Bostân ve Gülistân isimli eserleri Osmanlı döneminde birkaç defa Türkçeye tercüme ve şerh edilmiştir. 16. Asırda yaşayan Bosnalı Sûdî Bosnevî’nin Bostan ve Gülistan üzerine yazdığı iki Türkçe şerh 20. Yüzyllda Farsçaya tercüme edilip neşredilmiştir. Sûdî’nin şerhleri Osmanlı döneminde neşredilmiş ise de, Türkiye'de bugün itibariyle o eski baskı eserleri okuyabilecek insan çok azdır.

Hicrî 9. (m. 15.) yüzyıla kadar İran coğrafyasında yazılmış birçok klasik tasavvufî eser Osmanlı Türkçesine tercüme edilmiş ise de, bu asırdan sonra tercümeler yön değiştirmiştir. Hicrî 9. Asırdan sonra yapılan tercümelere baktığımızda bunların, Orta Asya' da gelişen Nakşbendiyye tarîkatı mensuplarının eserleri olduğu anlaşılmaktadır. Bahâeddin Nakşbend'in müridlerinden Buharalı Muhammed Pârsâ'nın Risâle-i Kudsiyye ve Faslü'l-hitâb gibi eserleriyle başlayan bu tercüme faaliyetleri, birçok Nakşbendî müellifin Farş̧a eserlerinin Türkçeye tercüme edilmesiyle devam etmiştir. Nakşbendîliğin hicrî 11. (m. 17.) yüzyılda Hindistan'da Müceddidiyye kolu adıyla yayılmaya başladığı dönemden itibaren de Hindistan'daki Nakşbendîlerin eserleri Türkçeye tercüme edilmeye başlanmıştır. Yani miladî 15-19. Yüzyıllar arasında yazılan Farsça eserlerden yapılan tercümeler Orta Asya, Afganistan veya Hindistan Nakşbendîlerinin eserleridir.

Yani miladî 11-15. Yüzyıllar arasında İran'da yazılan Farsça eserler farklı dönemlerde Türkçeye çevrilmiş ise de, 15-19. Asırlar arasında yazılıp Türkçeye tercüme edilen eserler genellikle Nakşbendî mensuplarının eserleridir. Bunun belki de tek istisnâsı, Hindistanlı bir Çiştî şeyhi olan İmdâdullah Thânevî’nin Ziyâü'l-kulûb ve Risâle-i Vahdetü'l-vücûd isimli eserlerinin Türkçe tercümeleridir. Gerçi İmdâdullah'ın Çiştiyye'nin yanısıra Nakşbendiyye'den de icâzetli olduğu düşünülürse, bu da bir istisnâ sayılmayabilir. 15. Asırdan sonra İran top- 
raklarında yazılan Farsça eserler, İslam dünyasında yeterince yankı uyandıracak değerde bulunmamış ve tercümeye gerek görülmemiştir.

20. yüzyılda iş tersine dönmüş, Türkçeden Farsçaya bazı tercümeler yapılmıştır. Osmanlı döneminde yazılmış olan Türkçe Mesnevî, Bostân ve Gülistân şerhleri, Türkiye'de henüz yeni harflere aktarılmadan önce İran'da Farsçaya çevrilmiş ve okuyucuların istifadesine sunulmuştur. Ancak yine de, tarih içinde Farsçadan Türkçeye tercüme edilen eserlerin sayısı ile Türkçeden Farsçaya tercüme edilen sayısı karşılaştırıldığında arada büyük bir uçurum vardır. Türkçeden Farsçaya çevrilen eser sayısı oldukça azdır ve 20. Yüzyıla kadar neredeyse hiç yoktur.

Şimdi Osmanlı döneminde Farsçadan Türkçeye tercüme edilen tasavvufî eserlere bir göz atalım:

\section{Abdullah Ensârî Herevî (ö. 481/1089), Münâzara-i Dil ü Cân, Kenzü̈'s-sâlikîn.}

Abdullah Ensârî Herevî’nin Münâzara-i Dil ü Cân isimli Farsça tasavvufî eseri Osmanlı döneminde Osmanlı Türçesine kısaltılarak tercüme edilmiştir. Bu tercümenin yazma bir nüshası İstanbul'da Millet Kütüphanesi'ndedir'. Nüsha, Herevî nin Dil ü Cân ve Vâridât isimli risâlelerinden seçilmiş kısımlardan oluşmaktadır. Mütercimi Mehmed es-Süleymânî el-Hâlidî isimli bir zâttır. 19. asırda yapıldığı tahmin edilen bu Osmanlıca tercüme, yeni harflere (latin) aktarllıp neşredilmiştir ${ }^{2}$.

Abdullah Ensârî Herevî’nin Kenzü s-sâlikîn isimli Farsça eserinin "Şeb u Rûz" başlıklı bölümü de bazı kısaltma ve ilâvelerle birlikte Mevleviyye tarîkatından Fasîh Ahmed Dede (ö. 1111/1699) tarafindan Münâzara-i Rûz u Şeb adıyla Osmanlı Türkçesine tercüme ve neşredilmiştir (İstanbul 1278). Ayrıca eserden alınan bazı parçalar Mebâliğu'l-hikem adıyla şair Nevres tarafından Türkçeye çevrilmiştir (nşr. Ebüzziyâ Tevfik, İstanbul 1302). Nevres, eseri Herevî’nin Ey Dervî̧ adlı kitabından tercüme ettiğini söylüyorsa da çeviri, başta Kenzü s-sâlikîn olmak üzere Herevî’nin diğer eserlerinden derlenerek meydana getirilmiştir³. 


\section{İmâm Gazâlî (ö. 505/1111), Kîmyâ-yı Saâdet.}

Gazâlî, meşhur Arapça eseri İhyâü ulûmiddîn'i Arapça bilmeyenler de okuyabilsin diye Farsçaya kısaltarak tercüme etmiş ve bu tasavvufî eserine Kîmyâ-yı Saâdet adını vermiştir. Kîmyâ-yı Saâdet Osmanlı döneminde Türkçeye birkaç defa tercüme edilmiştir. Bazı mütercimler şunlardır: Hüsâmeddin b. Hüseyin Sehâbî (ö. 971/1564)" Vankulu lakaplı Muhammed b. Mustafa Vânî (ö. 1000/1592) ${ }^{5}$, La'lîzâde Abdülbâkî (ö. 1159/1746) ${ }^{6}$. Not: Gazâlî’ye nisbet edilen Nasîhatü'l-mülûk isimli Farsça eser de Osmanlı döneminde Türkçeye birkaç defa tercüme edilmiştir. Ancak bu eser tasavvufî değil, siyâsetnâme türünde olduğu için burada ondan bahsedilmeyecektir.

Aynü'l-kudât Hemedânî (ö. 525/1131), Temhîdât (Kenzü'lhakâyık ve keşfü'd-dekâyık).

Aynü'l-kudât'ın Temhîdât adıyla bilinen Farsça tasavvufî eseri, Osman11 döneminde 16. Yüzyıl şâirlerinden Üsküdarlı Aşkî (İlyâs Çelebi) tarafından Kenzü'l-hakâyık ve keşfü'd-dekâyık Tercümesi adıyla Türkçeye tercüme edilmiş ve Padişah II. Selîm'e sunulmuştur?

\section{Ebû Bekir b. Muhammed Seylânî Merendî (ö. 561/1166'dan sonra), Necâtü'z-zâkirîn.}

Hicrî 6. Asırda yaşamış olan Ebû Bekir Seylânî Merendî̀ ${ }^{8}$ Necâtü'z-zâkirîn ${ }^{9}$ Fazlü'l-fukarâ ale'l-agniyâ ${ }^{10}$, el-Havf ve'r-recấ1 ${ }^{11}$ gibi Farsça eserler kaleme almıştır. Bu eserlerden Necâtü'z-zâkirîn, duâ ve duânın faziletiyle ilgili bir eser olup, Osmanlı döneminde Musa b. Hacı Hüseyin İznikî (ö. 838/1434 ?) tarafından Zâdü'l-ibâd adıyla Türkçeye tercüme edilmiştir' ${ }^{12}$. Bu tercüme Süleyman Altıner tarafından yeni harflere çevrilip doktora tezi olarak hazırlanmıştır ${ }^{13}$.

\footnotetext{
7 Millet Ktp., Ali Emîrî Şer'iyye, nr. 786; İstanbul Belediye Ktp., Osman Ergin Yazmaları, nr. 421 (39 varak). Bkz. Sadık Yazar, "XVI. Yüzyıl Şâirlerinden Üsküdarlı Aşkî’nin Eserleri Hakkında Yeni Tespitler”, Türkiyat Mecmuası, c. 21 (2011), s. 375-393. Harun Turhan, Aşkî (Aynü'l-kuzat Ali Hemedânî)'nin Kenzü'l-hakaik ve keşfü'd-dekaik, Pamukkale Üniversitesi Sosyal Bilimler Enstitüsü, Yüksek Lisans Tezi, Denizli 1998.

8 Bk. Bağdatlı İsmail Paşa, Hediyyetü'l-ârifin, Beyrut ts., c.1, s. 212.

9 Süleymaniye Ktp, Fâtih, nr. 2878; Süleymaniye Ktp., Ayasofya, 2809; Eskişehir İl Halk Ktp., nr. 597; Ankara, Millî Ktp. Yazmalar, A 9514

10 Afyon, Gedik Ahmed Paşa İl Halk Ktp., nr. 18267/2 (vr. 35a-114a)

11 Afyon, Gedik Ahmed Paşa İl Halk Ktp., nr. 18267/1 (vr. 1-35a)

12 Süleymaniye Ktp., Hamidiye, nr. 635 (154 varak). Mütercim hakkında bkz. M. Kâmil Yaşaroğlu, "Mûsâ İznikî”,

Diyanet İslam Ansiklopedisi, İstanbul 2006, c. 31, s. 218-219.

13 Süleyman Altıner, Ebu'l-Fazl Musa İznikî'nin Zâdu'l-İbâd (Kullara Gıda) Adlı Eseri (Giriş, Dil İncelemesi, Metin, Sözlük, Dizin), İstanbul Üniversitesi Sosyal Bilimler Enstitüsü, doktora tezi, 2017. Necâtü’z-zâkirîn doğrudan tasavvufî konularda bir eser olmamakla beraber, tasavvufta duâ ve zikre özel bir önem verildiği ve müellifi Seylânî’nin diğer iki eserinin tasavvufî olması sebebiyle bu eser bu makaleye dâhil edilmiştir.
} 


\section{Ebû Nasr Tâhir Hânkâhî (ö. 550/1155'ten sonra), Güzîde.}

Hicrî 6. Asırda Serahs’ta yaşayan Ebû Nasr Tâhir b. Muhammed Hânkâhî’nin ahlak ve tasavvuf konularında kaleme aldığı Güzîde isimli Farsça eser İran'da Îrec Efşâr tarafından yayınlanmıştır ${ }^{14}$. Bu eser Osmanlı döneminde hicrî 10 asırda Muhammed b. Bâlî tarafindan Osmanlı Türkçesine tercüme edilmiştir. Türkiye kütüphanelerinde yazma nüshaları bulunan eser $^{15}$, latin (yeni Türk) harflerine çevrilerek neşredilmiştir ${ }^{16}$. Avrupa' da Uppsala ve Viyana kütüphanelerinde de Türkçe tercümenin yazma nüshaları vardır.

\section{Ferîdüddin Attâr (ö. 618/1221), Tezkiretü 'l-evliyâ; İlâhînâme; Esrârnâme; Mantıku't-tayr; Pendnâme, Muhtârnâme, Musîbetnâme.}

Tezkiretï'l-evliyâ: Ferîdüddin Attâr'ın evliâ menkıbelerini ihtivâ eden bu mensûr Farsça eseri Osmanlı döneminde birkaç Türkçeye tercüme edilmiştir. Anadolu sahasında Ahmed-i Dâî, Ali Rızâ Karahisârî, İbrâhim b. Bâyezîd, Mustafa Hemedânî gibi şahıslar tarafından Türkçeye çevrilen Tezkiretü'l-evliyâ'nın en meşhur mütercimi ise Sinan Paşa'dır. Sinan Paşa'nın Tezkiretü'l-evliyâ adlı tercümesi, Attâr'ın eserindeki ilk yirmi sekiz bölümün yer yer kısaltılıp ilâveler yapılarak hazırlanmış bir tercümesi niteliğindedir. Eserin ilmî neşri Emine Gürsoy Naskali tarafından gerçekleştirilmiştir (Sinan Paşa, Tezkiretü'l-evliyâ, Ankara 1987).

İlâhînâme: Attâr'ın bu Farsça manzum eseri Osmanlı döneminde Şemseddin Sivâsî (ö. 1006/1597) tarafından İbretnümâ adıyla manzum olarak Türkçeye çevrilmiş (Beyazit Devlet Ktp., Bayezid, nr. 3315) ve Sultan III. Murad'a takdim edilmiştir. Bu tercüme yeni harflerle de neşredilmiştir ${ }^{17}$.

Esrârnâme: Attâr'ın bu Farsça manzum eseri XV. Yüzyılda Akkoyunlular döneminde Tebrîz'de yaşayan Ahmedî (ö. 884/1480'den sonra) tarafından Türkçeye tercüme edilmiştir. Tercümenin Gönül Ayan tarafından yeni harfli neşri de yapılmıştır ${ }^{18}$. Esrârnâme, Gelibolulu Huzûrî tarafindan da Türkçeye çevrilmiştiri' ${ }^{19}$.

14 Ebû Nasr Hânkâhî, Güzîde der Ahlâk ve Tasavvuf (nşr. Îrec Efşâr), Tahran 1347 hş. /1966.

15 Tercümenin bazı nüshaları: Süleymaniye Ktp., Hacı Mahmud, nr. 1935 (105 varak); Millet Ktp., Ali Emîrî Şer’iyye, nr. 1343 (vr. 94-126); Bursa Bölge Ktp., Orhan, nr. 676 (101 varak).

16 Ebû Nasr Serahsî, Kitab-ı Güzide: Akaidü'l-İslam: Giriş, metin, dizin-sözlük, tıpkıbasım, (hzr. Serhat Küçük), İstanbul: Kesit Yayınları, 2014.

17 Şemseddin Sivasi, İbretnümâ (hzr. Erol Çöm), Sivas 2015.

18 Topkapı sarayı Müzesi Ktp, Bağdat, nr. 400; İstanbul Belediye Ktp., Belediye Yzm. nr. K-892 (vr. 1b-42b). Eserin yeni harfli metin neşri: Gönül Ayan, Tebrizli Ahmedî- Esrâr-nâme (Inceleme, Metin), Ankara 1996; Tüba Ceylan, Tebrizli Ahmedi'nin Esrarnâme Tercümesi, Selçuk Ün. Sosyal Bilimler Enstitüsü, Konya, 2007 (yayınlanmamış yüksek lisans tezi); Nihat Azamat, "Yeni Bir Ahmedi ve İki Eseri: Yûsuf u Zelîha, Esrarnâme Tercümesi”, Osmanlı Araştırmaları, sy. VII-VIII (1988), s. 347-364.

19 Tuba Mersin, Gelibolulu Huzûrî’nin Tercüme-i Esrâr-nâme Adlı Mesnevîsi, Fatih Üniversitesi Sosyal Bilimler Enstitüsü, YL tezi, İstanbul 2004. 
Mantıku't-tayr: Kuşların konuşması, yolculuğu ve mâcerâları üzerinden tasavvufî ahlak ve vahdet-i vücûd konularının ele alındığı Attâr'ın bu manzum Farsça eseri Osmanlı döneminde Türkçeye birkaç defa tercüme edilmiştir. Türk edebiyatında önemli yeri ve etkisi olan Matıku't-tayr' 1 Gülşehrî manzum olarak hicrî 717 'de (mîlâdî 1317) Türkçeye çevirmiştir. Mantıku 't-tayr veya Gülşennâme adını taşıyan eserin hâtime bölümünde Gülşehrî, Mantıku't-tayr'ı esas almakla birlikte başka bir eser meydana getirdiğini ve eserinin telif sayıldığını söylemektedir. Bu tercüme Müjgân Cunbur tarafından yeni harflere çevrilmiştir (doktora tezi, Ankara 1952) Mantıku't-tayr'ı yine manzum olarak Antepli Mevlevî Fedâyî Dede (ö. 1065/1655) Mantıku'l-esrâr (Millî Ktp., Yazmalar, nr. A. 3341) 20, Karatovalı Zaîfî Pîr Mehmed (ö. 964/1557’den sonra) Gülşen-i Sîmurg (Cem Dilçin, basılmamış lisans tezi, Ankara 1968) ve Kadızâde Şeyh Mehmed İnşirâku's-sadr (TDK Ktp., Fotokopi, nr. 38) adıyla Türkçeye çevirmiştir ${ }^{21}$. Osmanlı döneminde Şem’î Efendi (ö. 1011/1602 ?) Mantıku't-tayr üzerine Türkçe bir şerh yazmıştır²2. Mantıku't-tayr' 'n bilinen ilk ve tek klasik şerhi bu eserdir ${ }^{23}$.

Pendnâme: Ferîdüddin Attâr'a nisbet edilen bu Farsça eser de Osmanlı döneminde Edirneli Nazmî tarafindan h. 967 (1599) senesinde Tercüme-i Pend-i Attâr veya Pend-nâme-i Nazmî adıyla Türkçeye tercüme edilmiştir ${ }^{24}$. Başka tercümeleri de vardır25 ${ }^{25}$ Eser, İsmâîl Hakkı Bursevî (ö. 1137/1725) ${ }^{26}$ ve Muhammed Murâd Nakşbendî (ö. 1264/1848) ${ }^{27}$ tarafindan da Türkçeye tercüme ve şerh edilmiştir.

20 Tacettin Şimşek, Fedayi Dede, Mantık-ı Esrâr: Tenkidli Metin-İnceleme, Yüksek Lisans Tezi, Atatürk Üniversitesi, Sosyal Bilimler Enstitüsü, Erzurum 1993; Güler Doğan Averbek, "Fedâyî Mehmed Dede Mantık-1 Esrâr Adlı Manzûm Mantıku’t-tayr Tercümesi ve Otograf Nüshası”, Uluslararası Türkçe Edebiyat Kültür Eğitim Dergisi, c. 6, sy. 3 (2017), s. $1490-1506$.

21 H. Ahmet Sevgi, "Mantıku't-tayr”, Diyanet İslam Ansiklopedisi, İstanbul 2003, c. 28, s. 29-30.

22 Şerh-i Mantıku't-tayr, Yeniçeri Ağası Tırnakçı Hasan Ağa'ya ithaf edilmiştir (Süleymaniye Ktp., Cârullah Efendi, nr. 1716; Millet Ktp., Ali Emîrî Efendi, nr. 1185). Şem'î, Şerh-i Mantıku’t-tayr (hzr. Muhittin Turan), İstanbul: Kesit Yayınlar1, 2015.

23 Bihrûz Servetiyân'ın Şerh-i Râz-1 Mantıku’t-tayr-1 Attâr (Tahran: Emîr-i Kebîr, 1384 hş./2005) isimli yeni eseri, klasik bir çalışma değildir.

24 Ankara Ün. Dil ve Tarih Coğrafya Fakültesi Ktp., Muzaffer Ozak Kitapları, nr. I/1061. Edirneli Nazmî, Pend-nâme-i Nazmî (hzr. Kudret Altun), Kayseri: Laçin Yayınları, 2014. Mustafa Özkan, "Edirneli Nazmî”, Diyanet İslam Ansiklopedisi, İstanbul 1994, c. 10, s. 450-451.

25 Pendnâme'nin manzum tercümeleri için bkz. Serkan Türkoğlu, “Türk Edebiyatında Pendnâme-i Attâr'ın Manzum Tercümeleri ve Seyyid Ali Rızâ'nın Riyâzü'r-Rızâ'sı”, Atatürk Üniversitesi Sosyal Bilimler Enstitüsü Dergisi,sy. 22 (Nisan 2018), s. 671-692.

26 Şerh-i Pend-i Attâr (Trc. Ve şerh: İsmail Hakkî Bursevî), İstanbul: Dârü't-tıbâ'ati'l-âmire, 1250/1834. (7+689 sayfa). 27 Kitâb-ı Mâ Hazar Şerh alâ Pend-i Attâr (trc. ve şerh: Muhammed Murâd Nakşbendî), İstanbul: Matbaa-i Ấmire, 1252/1836 (267 sayfa); Eser yeni harflere çevrilip yayınlanmıştır: Mehmed Murad Nakşibendî, Pendnâme-i Attâr Şerhi, (hzr. M. Altaytaş, E.H. Yiğit), İstanbul: Büyüyen Ay Yayınevi, 2012; Molla Murad en-Nakşibendî, Aşk Bağından Öğütler: Mâ Hazar Pendnâme Şerhi (hzr. İbrahim Kunt, M. Ali Özkan), İstanbul: Semerkand Yayınları, 2013. 
Muhtârnâme: Attâr'1n Farsça manzum bir eseri olan Muhtârnâme, elli bölümden oluşan bir rubâîler mecmuasıdır. Osmanlı döneminde 16. Yüzyı1 şâirlerinden Üsküdarlı Aşkî tarafından muhtasaran Türkçeye tercüme edilmiştir ${ }^{28}$.

Musîbetnâme: Attâr'1n bu Farsça eseri, XV. Yüzyılda Pîr Mehmed tarafindan Tarîkatnâme ya da Tercüme-i Musîbetnâme-i Attâr adıyla Osmanlı Türkçesine tercüme edilmiştir. Eser 826 (1423) senesinde tamamlanmış olup II. Murad'a takdim edilmiştir ${ }^{29}$.

\section{Şems-i Tebrîzî (ö. 645/1247 ?), Mergûbu'l-kulûb}

Mevlânâ Celâleddin Rûmî'nin sohbet arkadaşı olan Şems-i Tebrîzî’ye nisbet edilen Mergûbu'l-kulûb isimli bu Farsça manzum ve küçük eserin ona aidiyeti tartışmalıdır. Hicrî 7. yüzyılda Hind Alt Kıtası'ndaki Multân'da vefat eden Şems-i Tebrîzî Multânî’ye ait olabileceğini düşünen araştırmacılar da vardır. Birçok yazma nüshası olan bu Farsça tasavvufî eser, İran'da makale şeklinde yayınlanmıştır ${ }^{30}$. Mergûbu 'l-kulûb Osmanlı döneminde Emîrî diye bilinen Mehmed b. Musa Paşa (ö. 1005/1595'den sonra) tarafindan Şems-i Tebrîzî'ye nisbet edilerek Türkçeye nazmen tercüme edilmiştir. Bu tercüme İsa Akpınar tarafından makale olarak neşredilmiştir ${ }^{31}$.

\section{Necmeddin-i Dâye (ö. 654/1256), Mirsâdü 'l-ibâd.}

Necmeddin-i Kübrâ'nın mürid ve halifesi olan Necmeddin-i Dâye'nin kaleme aldığı Mirsâdü'l-ibâd mine'l-mebde'ile 'l-me'âd isimli Farsça tasavvufî eseri Osmanlıca döneminde h. 825 (1422) senesinde Kâsım Karahisârî (ö. 15. Asır) tarafından İrşâdü'l-mürîd ile'l-murâd fî̀ tercemeti Mirsâdi'l-ibâd adıyla Türkçeye tercüme edilip padişah II. Murad'a ithâf edilmiştir ${ }^{32}$. Birçok yazma nüshası olan tercüme, Ahmet Çal tarafından yüksek lisans tezi olarak çalışılmış ve yeni harflere aktarılmıştır ${ }^{33}$.

\footnotetext{
28 İstanbul Belediye Ktp., Osman Ergin Yazmaları, nr. 704/13; Süleymaniye Ktp., Yazma Bağıșlar, nr. 6647 (vr. 51b-81b). Bkz. Sadık Yazar, "XVI. Yüzyıl Şâirlerinden Üsküdarlı Aşkî’nin Eserleri Hakkında Yeni Tespitler”, s. 375-393. 29 Sadık Yazar, Anadolu Sahası Klâsik Türk Edebiyatında Tercüme ve Şerh Geleneği, İstanbul Üniversitesi Sosyal Bilimler Enstitüsü, Dr. Tezi, 2011, s. 412-414.

30 Sîmâ Yârahmedî- Gulâm Rızâ Dâdhâh, "Mergûbu'l-kulûb”, Ittılâ'ât-ı Hikmet ve Ma'rifet, sy. 8 (1386 hş./2007), s. 50-55.

31 İsa Akpınar, "XVI. Asır Şairlerinden Emîrî’nin Mergûbu'l-kulûb Tercümesi”, Türk Kültürü ve Hacı Bektaş Veli Araştırma Dergisi, sy. 89 (Bahar 2019), s. 147-167.

32 Ahmet Çal, "Kasım b. Mahmud Karahisarî'nin İrşadü'l-mürid ile'l-murâd fî̀ tercemeti Mirsâdi'l-ibâd Adlı Eseri”, Turkish Studies, c. 10-12 (2015), s. 233-248.

33 Ahmet Çal, Kasım b. Mahmud Karahisarî'nin İrşadü 'l-mürid ile'l-murad fi tercemeti Mirsadi'l-ibad (Inceleme-Metin-Dizin), Fırat Üniversitesi Sosyal Bilimler Enstitüsü, Yüksek Lisans Tezi, Elazığ 2008.
} 


\section{Mevlânâ Celâleddin-i Rûmî (ö. 672/1273), Mesnevî-yi Ma'nevî;}

\section{Fîhi Mâ Fîh.}

Mesnevî: Mevlânâ'nın meşhur Farsça eseri Mesnevî Osmanlı döneminde çok defa Türkçeye tercüme ve şerh edilmiştir. En meşhur tercüme ve şerhi İsmâil Rusûhî Ankaravî’ye (ö. 1041/1631) aittir ${ }^{34}$. Bu şerh, İsmet Settârzâde tarafindan Şerh- Kebîr-i Ankaravî ber Mesnevî-yi Ma’nevî-yi Mevlevî adıyla Türkçeden Farsçaya çevrilip neşredilmiştir (Tahran 1348 hş./1970).

Ahmed Avni Konuk (ö. 1938) ${ }^{35}$ tarafindan yapılan tercüme ve şerh Osmanlıca el yazısı defterler şeklinde olup Mustafa Tahralı ve arkadaşları tarafından Mesnevî̀ $i$ Şerîf Şerhi adıyla yeni harflere çevrilerek 13 cilt hâlinde basılmıştır (İstanbul: Kitabevi Yayınları, 2006-2009).

Fîhi Mâ Fîh: Mevlânâ'nın sağlığında oğlu Sultan Veled veya bir başka müridi tarafindan kaydedilen sohbetlerinin vefatından sonra derlenmesinden meydana gelmiş olan Farsça mensûr bir eserdir ${ }^{36}$. Ahmed Avni Konuk (ö. 1938) tarafından yapılan Osmanlıca tercümesi Konya Mevlânâ Müzesi Kütüphanesi’nde olup (nr. 3895), Selçuk Eraydın tarafindan Osmanlıca el yazısından yeni harflere çevrilerek yayınlanmıştır (İstanbul: İz Yayıncılık, 1995.

\section{Sadreddin Konevî (ö. 673/1274), Tebsıratü'l-mübtedî ve tezkiretü'l-müntehî.}

Sadreddin Konevî'ye nisbet edilen Tebsıratü'l-mübtedî isimli Farsça tasavvufî eser, Osmanlı son döneminde Ahmed Remzi Dede el-Mevlevî (Akyürek, ö. 1944) tarafından hicrî 1340 (1921) senesinde Türkçeye tercüme edilmiş$\operatorname{tir}^{37}$. Bu tercüme Ekrem Demirli tarafından Marifet Yolcusuna Kılavuz adıyla yeni harflerle neşretmiş̧ir (İstanbul: İz Yayıncılık, 2002) 3 $^{38}$

\footnotetext{
34 Mesnevî Şerhi: Mecmûatü'l-letâif ve ma'mûretü'l-ma' ârif, Misır 1221/1806; İstanbul 1257. Mesnevî'nin diğer Türkçe tercüme ve şerhleri için bkz. Semih Ceyhan, "Mesnevî”, Diyanet İslam Ansiklopedisi, İstanbul 2004, c. 29, s. 325-334. 35 Reşat Öngören, “Konuk, Ahmet Avni”, Diyanet İslam Ansiklopedisi, İstanbul 2002, c. 26, s. 180-182. 36 Nşr. Bedîüzzamân Fürûzânfer, Tahran 1335 hş.

37 Sadreddin Konevî, Tebsıratü'l-mübtedî tezkiretü'l-müntehî, trc. Ahmed Remzî el-Mevlevî, İstanbul Belediye Ktp., Osman Ergin Yazmaları, nr. 327 (56 varak). Eserde sağ tarafta Farsça metni, sol tarafta Türkçe tercümesi vardır. 38 Mikail Bayram Tebstratü 'l-mübtedî’yi Ahî Evren'e (ö. 659/1261) nisbet ederek Tasavvufì Düşüncenin Esasları adıyla yeni bir tercümesini yapmışırır (Ankara: Türkiye Diyanet Vakfı Yayınları, 1995).
} 


\section{Şeyh Sa'deddin (7./ 13. asır), Menâkıbnâme-i Şeyh Evhadüd- din Kirmânî}

Hicrî 7. Asır şeyhlerinden Evhadüddin Kirmânî’nin (ö. 635/1238) hayatını v menkıbelerini ihtivâ eden bu Farsça eser Bedîuzzamân Fürûzânfer tarafından neşredilmiştir ${ }^{39}$. Fürûzânder bu eserin müellifinin meçhul olduğunu kaydetmiştir. Eser Osmanlı döneminde Muhyiddin Gelibolî tarafından Türkçeye tercüme edilmiştir. Mütercim bu eserin Farsça aslının Evhadüddin'in mürid ve halifelerinden Şeyh Sa'deddin tarafından kaleme alındığını kaydetmiştir ${ }^{40}$. Böylece meçhul sanılan müellif de belli olmuştur. Şeyh Sa'deddin, Evhadüddin Kirmânî’nin müridi olduğuna göre o da şeyhi gibi hicrî 7. (miladî 13.) asırda yaşamış olmalıdır. Osmanlı döneminde Gelibolulu Muhyiddin tarafından Farsçadan Türkçeye çevrilen eserin iki yazma nüshası bilinmekte olup ${ }^{41}$, İsmail Hakkı Mercan tarafından yüksek lisans tezi olarak hazırlanmış ve yeni harflere çevrilmiştir ${ }^{22}$.

\section{Fahreddin-i Irâkî (ö. 688/1289), Lema'ât}

Lema'ât Osmanlı döneminde birkaç defa Türkçeye tercüme edilmiştir. İlk tercüme, Hacı Bayram Velî’nin (ö. 833/1430) müridlerinden İnce Bedreddin tarafindan miladî 15. Yüzyılda yapılmıştır. Bu tercümenin Türkiye kütüphanelerinde yirmiden fazla yazma nüshası vardır ${ }^{43}$. Eser, yeni harflere çevrilerek yayınlanmıştır ${ }^{44}$. Lema' $a t^{\prime}$ 'n Osmanlıca ikinci tercümesi Abdülmecîd b. Nasûh Tosyavî’ye (ö.

39 Menâkıb-ı Evhadüddîn Hâmid b. Ebi'l-Fahr Kirmânî (nşr. Bedîuzzamân Fürûzânfer), Tahran 1347 hş./1969. Fürûzânfer bu neşri yaparken Süleymaniye Ktp., Nâfiz Paşa, nr. 1119'daki nüshayı kullanmıştır. Bu nüsha hâricinde eserin Farsçasının şu nüshaları da vardır: Edirne, Selimiye Ktp., nr. 2140; Karaman Kütüphanesi, nr. 2.

40 "Şeyh Evhadüddin Kirmânî rahmetullâhi aleyh rahmeten hazretinin cümle-i halîfelerinden bir kâmil halifesi var idi, adına Şeyh Sa'deddin derlerdi. Kendisi pârsî kitâbında şöyle buyurdu kim: Hazret-i Şeyh'in menâkıbı bî-kıyâsdır. Ammâ ba'zı menâkıbı kim her yerlerde dağılmış idi, cem' idüp bir kitâb eyledüm, tâ kim mu’tekıdlere ve mürîdlere ve muhiblere istirşâd-1 yakîn ve fâide-i dîn hâsıl ola. Ve dahi bileler kim Hazret-i Şeyh ne kadar belâ ve çileler çelmişdür, tâ ma'rifet gencine erişinceye değin. Ve bu za'îf-i nahîf-i dâ'î kâtib Muhyiddin Gelibolî gufrâne lehû ve li-cemî'i ehli'l-îmân eydür kim: Bu latîf menâkıbın pârsîsi elime girdi. Dâim mutâla’a ederdim. Bir gün şu vîrân gönlüme şöyle ilhâm olundu kim, bunun tercümesine ikdâm idem. Ammâ gördüm kim, lafzan bi-lafzın Türk̂̂’ye gelecek olursa mutavvel olup okuyan kimesnelere melâlet hâsıl olur. Ol ihtiyât içün ba'zı hikâyetlerinin mâ hasalın çıkarub tercüme eyledüm. Tâ kim pârsîden hazzı olmayanlara fâide ola". Muhyiddin Gelibolî, Terceme-i Menâkıbnâme-i Şeyh Evhadüddin Kirmânî, Konya İzzet Koyunoğlu Müze Ktp., nr. 13289, vr. 1a-1b.

41 Konya İzzet Koyunoğlu Müze Ktp., nr. 13289 (121 varak); Mustafa Okkesim şahsî kütüphanesindeki nüsha (133 varak). Mütercimin hangi asırda yaşadığı bilinmemektedir.

42 İ. Hakkı Mercan, Menâkıbnâme-i Şeyh Evhadeddin Kirmânî (YL tezi), Kayseri 1990.

43 Meselâ: İnce Bedreddin, Tercüme-i Leme ât, Süleymaniye Ktp., Hacı Mahmud Efendi, nr. 3096 (94 varak); İstanbul Belediye Ktp., Osman Ergin Yazmaları, nr. 1387 (58 varak). Bu tercüme hakkında detaylı bilgi için bkz. Ercan Alkan, "Hacı Bayram-1 Velî'nin İsteğiyle Yapılan Bir Tercüme: İnce Bedreddin ve Tercüme-i Lema'ât'ı", Tasavvuf: İmî ve Akademik Araştırma Dergisi, sy. 31 (2013), s. 57-73.

44 Fahreddin Irakî, Lemaât (nşr. Hanifi Vural), İstanbul: Kesit Yayınları, 2017. 
996/1588) aittiri5. Üçüncü tercüme ise Ahmed Avni Konuk'a (ö. 1938) âittir. Bu son tercüme Ercan Alkan tarafindan yeni harflerle yayınlanmıştır ${ }^{46}$.

\section{Sa’ dî Şîrâzî (ö. 691/1292), Gülistân, Bostân}

Gülistân: Sa'dî Şîrâzî’nin ahlâkî ve tasavvufî eseri Gülistân, Osmanlı döneminde ilk kez 15. yüzyılda Mahmûd b. Kâdî-i Manyâs tarafindan Türkçeye tercüme edilmiştir ${ }^{47}$. Bu zât Gülistân'ı biri manzum ve ilâveli, biri de mensûr ve muhtasar olarak iki farklı şekilde Türkçeye tercüme etmiş ve miladî 1430 yılında bu tercümeleri Sultân II. Murâd'a hediye etmiştir ${ }^{48}$. Bunun ardından Osmanlı döneminde Gülistân'ın birçok tercüme ve şerhi yapılmıştır ${ }^{49}$.

Muhammed Sûdî Bosnevî (ö. 1007/1599'dan sonra) ${ }^{50}$ Gülistân üzerine Şerh-i Gülistân adıyla Türkçe bir şerh yazmıştır. İstanbul'da beş defa neşredilen $\operatorname{eser}^{51}, 2012$ 'de yeni harflerle de yayınlanmıştır ${ }^{52}$. Sûdî Bosnevî’nin bu şerhi, Haydar Hoştînet, Zeynelâbidîn Çâvuşî ve Ali Ekber Kâzımî tarafindan Şerh-i Sûdî ber Gülistân-1 Sa'dî adıyla Farsçaya tercüme edilip neşredilmiştir (Tahran 1349 hş./1971).

Bostân: Sa'dînin bir diğer Farsça eseri olan Bostân da Osmanlı döneminde birçok defa tercüme ve şerh edilmiştir. Manzûm ve tam olarak tercüme edenler şunlardır: Za'îfî (ö. 964/1557'den sonra), Bâ̆̆-ı Behişt adıyla manzum ve tam ilk tercümeyi 16. Yüzyılda (956/1549 senesinde) yapmıştır ${ }^{53}$. Abdî, yine 16. Yüzyılda Bostân Tercümesi adıyla 963/1556 senesinde tamamladığı manzum tercümeyi Manisa'da şehzâde olan

45 Abdülmecîd Tosyavî, el-Lemehât fì tercemeti'l-Leme'ât, Kastamonu İl Halk Ktp., nr. 36, vr. 231b-246b. Mütercimin hayatı ve eserleri için bkz. Ufuk Hayta, Abdülmecîd b. Nasûh Tosyevî'nin (ö. 1588) Hayatı Eserleri ve el-Hüdâ ve'l-Felâh Adlı Tefsir Risalesinin Tahkiki, Uludağ Üniversitesi Sosyal Bilimler Enstitüsü, 2008.

46 Fahreddin-i Irâkî, Lemaât Aşka ve Âşıklara Dâir (trc. Ve şerh: Ahmed Avni Konuk, hzr. Ercan Alkan, İstanbul: İlk Harf Yayınevi, 2011.

47 Gülistân, Osmanlı sahası dışında ilk kez Seyf-i Sarâyî tarafından Memlûk Türkçesine h. 793 (miladî 1391) yılında, sonra İspîcâbî tarafindan Çağatay Türkçesine h. 800 (miladî 1397) yılında tercüme edilmiş ise de, bu makalede sadece Osmanlı dönemi tercümeleri ele alındığı için onlardan bahsedilmeyecektir. Farsçadan Orta Asya Türkçesi'ne yapılan Gülistân tercümeleri hakkında bkz. Necdet Tosun, Türkistan Dervişlerinden Yâdigâr: Orta Asya Türkçesiyle Yazılmış Tasavvufi Eserler, İstanbul 2011, s. 50-52.

48 Mustafa Özkan, Mahmûd b. Kâdî-i Manyâs Gülistân Tercümesi Giriş İnceleme Metin Sözlük, Ankara: Türk Dil Kurumu Yayınları, 1992.

49 Örnek olarak: Hüseyin Kefevî (ö. 1010/1601) Mekke'de kadı iken h. 1005 senesinde Gülistân'a Türkçe bir şerh yazmış ise de eser müsvedde hâlinde kalmış, daha sonra Kefevî’nin dostu Hüseyin b. Rüstem Paşa eseri düzenleyerek Bostân-l Efrûz-cihân der Şerh-i Kitâb-l Gülistân adıyla tamamlamıştır. Kayseri Râşid Efendi Ktp., nr. 566 (416 varak). Bkz. Kâtib Çelebi, Keş̧ 'u'z-zunûn, Beyrut ts., c. 2, s. 1054-1055.

50 Muhammed Aruçi, "Sûdî Bosnevî", Diyanet İslam Ansiklopedisi, İstanbul 2009, c. 37, s. 466.

51 İstanbul 1249, 1276, 1286, 1291; Şem 'î'nin şerhiyle birlikte, İstanbul 1293.

52 Sûdî-i Bosnevî, Gülistân Şerhi (nşr. Ozan Yılmaz), İstanbul: Çamlıca Basım Yayın, 2012.

53 Za'îfî, Bâğ-1 Behişt, İstanbul, Topkapı Sarayı Müzesi Kütüphânesi, Revân Köşkü, nr. 822. Mehmet Emin İnan, XVI. Asır Şâirleriden Za'îfî ve Bâğ-ı Behişt Mesnevîsi, Erciyes Üniversitesi Sosyal Bilimler Enstitüsü, YL tezi, Kayseri 1998. 
II. Selim'e sunmuştur ${ }^{54}$. Emîrî diye bilinen Mehmed b. Musa Paşa (ö. 1005/1595'den sonra) da Bostân'1 tercüme etmiştir ${ }^{55}$. 19. Yüzyılda Mehmed İzzet Paşa (ö. 1914) Gonca-i Bostân adıyla tercüme etmiş ve 1314/1898 yılında tamamlamıştır ${ }^{56}$.

Osmanlı döneminde Bostân, Muslihuddin Mustafa Sürûrî (ö. 969/1562) ${ }^{57}$ tarafından Farsça olarak şerh edilmiş ${ }^{58}$, bu Farsça şerh de 16. Yüzyılda Mehmed Rahmî tarafından Tuhfe-i Dûstân Şerh-i Bostân adıyla Türkçeye tercüme edilmiştir ${ }^{59}$. Bostan’1 Türkçe olarak şerh edenlerden biri de Şem'î lakabıyla anılan Şem'ullah Mehmed'dir (ö. 1011/1602) ${ }^{60}$. Bostân'1 Türkçe olarak şerh eden bir başka kişi Bosnalı Sûdî’dir (ö. 1007/1599'dan sonra). Sûdî Bosnevî, Bostân üzerine Mustafa Sürûrî, Şem‘î ve Bursalı Havâyî tarafından yapılan şerhleri beğenmemiş ve onların hatalarına da işaret ettiği Şerh-i Bostân isimli eserini kaleme almıştır. 1006/1598 senesinde tamamlanan bu şerh ${ }^{61}$ Osmanlı döneminde neşr edilmiştir. ${ }^{62}$ Eser, Ekber Bihrûz tarafından Şerh-i Sûdî ber Bostân-1 Sa 'dî adıyla Farsçaya çevrilmiştir (I-II, Tebriz 1352 hş./1973).

\section{Azîz Nesefî (ö. 700/1300 ?), Zübdetü'l-hakâyık, İnsân-ı Kâmil, Maksad-ı Aksâ.}

Zübdetü'l-hakâyık: Kübreviyye şeyhlerinden Sa'deddin Hammûye'nin müridi olan Azîz Nesefî' nin Zübdetü 'l-hakâyık isimli Farsça tasavvufî eseri, Hâfız Mehmed Ayıntâbî tarafından Gâyetü'd-dekâyık der Tercüme-i Zübdetü'l-hakâyık adıyla Türkçeye tercüme ve neşredilmiştir (Kâhire 1291/1874, 111 sayfa).

İnsân-1 Kâmil: Azîz Nesefî’nin İnsân-1 Kâmil adıyla anılan Farsça eseri Ahmed Avni Konuk (ö. 1938) tarafından Resâil-i Azîzüddin en-Nesefî Tercümesi adıyla Türkçeye çevrilmiş ${ }^{63}$ ve bu tercüme Sezai Firat tarafindan İnsan-1 Kâmil

\footnotetext{
54 Manisa İl Halk Kütüphanesi, nr. 2969 (169 varak). Hakan Sevindik, Türk Edebiyatında Bostan ve Abdî'nin Manzum Bostan Tercümesi (İnceleme-Metin), Selçuk Üniversitesi Sosyal Bilimler Enstitüsü, Doktora tezi, Konya 2014. 55 Emîrî, Bostân, İsveç, Uppsala Üniversitesi Ktp., O Vet 63, vr. 1b-70a. Bkz. İsmail Güleç- Güler Doğan Averbek, "Gölgede Kalmış Bir Şairin Bilinmeyen Üç Tercümesi”, Dil ve Edebiyat Araştırmaları, sy. 18 (Güz 2018), s. 255. 56 Mehmed İzzet Paşa, Gonca-i Bostân, İstanbul, Millet Kütüphanesi, Ali Emîrî Manzûm, nr. 1203 (160 varak). 57 Hayatı için nkz. İsmail Güleç, "Sürûrî, Muslihuddin Mustafa", Diyanet İslam Ansiklopedisi, İstanbul 2010, c. 38, s. 170-172.

58 Muslihuddin Mustafa Sürûrî, Şerh-i Bostân-1 Sa'dî, Beyazıt Devlet Ktp., Beyazıt bölümü, nr. 5775 (314 varak). 59 Mehmed Rahmî, Tuhfe-i Dûstân Şerh-i Bostân, Ankara, Milli Kütüphane Yazmaları, nr. A 6178. 60 Şeyda Öztürk, "Şem'̂̂", Diyanet İslam Ansiklopedisi, İstanbul 2010, c. 38, s. 503-504. Şem'î, Şerh-i Bostân-1 Şeyh Sa’dî, Beyazıt Devlet Ktp., Veliyyüddin bölümü, nr. 3666 (238 varak).

61 Beyazıt Devlet Ktp., Beyazıt bölümü, nr. 5793 (664 varak).

62 Sûdî Bosnevî, Şerh-i Bostân, İstanbul 1288/1871 (2 cilt, 604+402 sayfa).

63 İstanbul Belediye Ktp., Osman Ergin Yazmaları, nr. 80 (84 varak).
} 
adıyla yeni harflere aktarılıp yayınlanmışıır' ${ }^{64}$.

Maksad-ı Aksâ: Azîz Nesefî'nin Maksad-ı Aksâ isimli eseri de Osmanlı döneminde Abdullah b. Receb tarafindan Türkçeye tercüme edilmiştir ${ }^{65}$.

\section{Sipehsâlâr Ferîdûn b. Ahmed (ö. 712/1312 ?), Risâle-i Sipehsâlâr}

Mevlânâ Celâleddin Rûmî ve çevresindekiler hakkında bilgi veren Risâle-i Sipehsâlâr, Osmanlı döneminde iki defa Türkçeye tercüme ve neşredilmiştir. Mütercimlerden biri Ahmed Avni Konuk ${ }^{66}$, diğeri Midhat Bahârî Hüsâmî' dir ${ }^{67}$.

\section{Sultân Veled (ö. 712/1312), İbtidânâme, İntihânâme, Rebâbnâme.}

İbtidânâme: Mevlânâ Celâleddin Rûmî'nin oğlu olan Sultan Veled'in İbtidânâme (diğer adıyla Velednâme) isimli Farsça manzum eseri 16. Yüzyılda Konyalı Muhyî tarafindan nazmen Tercüme-i İbtidânâme adıyla Türkçeye tercüme edilmiştir. Eser, Mevlânâ, halîfeleri ve çevresi hakkında bilgiler vermektedir. Bu tercüme Cihan Okuyucu ve Sadık Yazar tarafindan yeni harflerle neşredilmiştir ${ }^{68}$.

İntihânâme: Sultan Veled'in İntihânâme isimli Farsça eseri, Niğdeli İbrahim Hakkı Eroğlu (ö. 1955) tarafından Osmanlı Türkçesine tercüme edilmiştir. Osmanlıca el yazması nüsha Selçuk Üniversitesi Merkez Kütüphanesi Mevlânâ Dökümantasyon Merkezi'ndedir. Eser, Hülya Küçük tarafından yeni (latin) harflere çevrilerek Küpten Sizan Sirlar: Intihâ-nâme-i Sultan Veled adıyla neşredilmiştir (İstanbul: Ataç Yayınları, 2010).

Rebâbnâme: Sultân Veled'in Rebâbnâme isimli eseri de yine İbrahim Hakk1 Eroğlu tarafından Osmanlı Türkçesine çevrilmiş, bu tercüme Amber Güneysel tarafından yeni harflere aktarılarak neşredilmiştir (Konya: Konya Valiliği İl Kültür ve Turizm Müdürlüğü Yayınları, 2011).

64 Azîzüddin Nesefî, İnsân-1 Kâmil (trc. A.Avni Konuk, hzr. Sezai Fırat), İstanbul: Gelenek Yayınları, 2010.

65 İstanbul Belediye Ktp., Osman Ergin Yzm., nr. 622 (182 varak); Süleymaniye Ktp., Hacı Mahmud, nr. 3166. Bkz. İbrahim Düzen, “Azîz Nesefî”, Diyanet İslam Ansiklopedisi, İstanbul 1991, c. 4, s. 344-346.

66 Sipehsâlâr, Menâkıb-ı Hazret-i Mevlânâ Celâleddin-i Rûmî (trc. Ahmed Avni Konuk), İstanbul 1331.

67 Sipehsâlâr, Tercüme-i Sipehsâlâr be Menâkıb-ı Hüdâvendigâr (trc. Midhat Bahârî Hüsâmî), İstanbul 1331.

68 Konyalı Muhyî, Tercüme-i İbtidânâme (hzr. Cihan Okuyucu- Sadık Yazar), Ankara: Türk Dil Kurumu Yayınları, 2018. 


\section{Hüseyin b. Âlim Hüseynî Sâdât el-Gûrî (ö. 718/1318 ?), Nüzhetï'l-ervâh.}

Sühreverdiyye tarîkatı şeyhi Bahâeddin Zekeriyyâ Multânî’nin mürid ve damadı olan Hüseynî Sâdât el-Gûrî'nin ${ }^{69}$ Farsça manzum ve mensur karışık olarak yazdığı Nüzhetü'l-ervâh, Osmanlı döneminde Divriğili Mehmed Sa'îd tarafindan Türkçeye tercüme edilmiş ve neşredilmiştir (İstanbul 1320/1902).

\section{Mahmûd Şebisterî (ö. 720/1320), Gülşen-i Râz,} Mir'âtü'l-muhakkıkîn.

Şebisterî’nin Farsça tasavvufî eseri Gülşen-i Râz Osmanlı döneminde Elvân-1 Şirâzî (ö. 829/1426'dan sonra) tarafından manzum olarak Türkçeye tercüme edilmiştir ${ }^{70}$. Bu tercüme yeni harflere çevrilmiş ve neşr edilmiştir ${ }^{71}$.

Muhammed b. Yahyâ Lâhîcî'nin (ö. 912/1506) yazdı̆̆g Mefâtîhu'l-i'câz fì şerhi Gülşen-i Râz isimli şerh, Osmanlı döneminde Cemâleddin Mahmud Hulvî (ö. 1064/1654) tarafindan Câm-ı Dilnüvâz adıyla özetlenerek Türkçeye tercüme edilmiştir ${ }^{72}$. Bu tercüme yeni harflere çevrilerek yayınlanmıştır ${ }^{73}$. Lâhîcî’nin Farsça şerhinden istifadeyle Gülşen-i Râz Şerhi adıyla Türkçe bir eser kaleme almaya başlayan Ahmed Avni Konuk ise 157. beyte kadar gelebilmiş, eseri tamamlayamamışıır ${ }^{74}$. Bu çalışma da yeni harflere aktarılarak yayınlanmışıır ${ }^{75}$.

Şebisterî'nin Mir'âtü'l-muhakkkkin isimli Farsça eseri de Osmanlı döneminde Abdullah Salâhî Uşşâkî tarafindan Türkçeye tercüme edilmiş ve bir mecmua içinde neşredilmiştir (İstanbul 1281, s. 95-106) ${ }^{76}$.

\section{Ali Râmîtenî (ö. 721/1321), Mahbûbu'l-ârifîn.}

Buhârâ'nın Râmîten köyünde doğan ve Harezm'de vefat eden Hâcegân tarîkatı şeyhlerinden Azîzân lakaplı Hoca Ali Râmîtenî’ye ${ }^{77}$ nisbet edilen ve tasavvuf-

69 Khaliq Ahmad Nizami, "Hüseynî Sâdât el-Gûrî", Diyanet İslam Ansiklopedisi, İstanbul 1999, c. 19, s. 24.

70 Şebüsterî, Tercüme-i Gülşen-i Râz, trc. Elvân-1 Şîrâzî, İstanbul Belediye Ktp., Osman Ergin Yazmaları, nr. 863 (106 varak).

71 Fatih Ülken, Elvan-ı Şirazî̀nin Gülşen-i Râz Tercümesi: Inceleme- Metin, Ege Üniversitesi Sosyal Bilimler Enstitüsü, Doktora Tezi, İzmir 2002; Muzaffer Akkuş, Elvan-l Şirazi'nin Gülşen-i Raz'l, Ankara 2002; Niğde 2004.

72 Süleymaniye Ktp., Șehid Ali Pașa, nr. 1253.

73 Cemâleddin Mahmud Hulvî, Câm-l Dil-nüvâz: Gülşen-i Râz Şerhi (hzr. Sait Okumuş), İstanbul: İnsan yayınları, 2012. 74 İstanbul Belediye Ktp., OE Yzm., nr. 1810.

75 Mahmûd-1 Şebusterî, Gülşen-i Râz (trc. Ve Şerh: Ahmed Avni Konuk, hzr. Cengiz Gündoğdu), İstanbul: İlk Harf Yayınları, 2011.

76 Matbû olmakla birlikte nâdir bulunan bu mecmuanın bir kopyası için bkz. Millet Ktp., Ali Emîrî Şer’iyye, nr. 212. 77 Ali Râmîtenî’nin hayatı ve eseri için bkz. Necdet Tosun, Bahâeddin Nakşbend: Hayatı Görüşleri Tarîkatı (XII-XVII. Astrlar), İstanbul 2002, s. 60-63. 
ta on makâmdan (usûl-i aşere) bahseden Mahbûbu'l-ârifin isimli Farsça küçük eser Hindistan'da taşbaskı şeklinde iki defa neşredilmiştir ${ }^{78}$. Eser, Osmanlı son döneminde Hocazâde Ahmed Hilmî (ö. 1914) ${ }^{79}$ tarafindan Türkçeye tercüme edilmiş ve Cerîde-i Sûfiyye isimli derginin 60 ve 61. sayllarında (1331/1913) neşredilmiştir ${ }^{80}$.

\section{Mahmûd b. Osman (ö. 728/1328'den sonra), Firdevsü'l- Mürşidiyye fí esrâri's-samediyye}

Ebû İshâk İbrâhîm Kâzerûnî’nin (ö. 426/1035) menakıbını ihtivâ eden Firdevsü'l-Mürşidiyye Farsça bir eserdir. Mahmûd b. Osman tarafindan hicrî 728 (1328) senesinde kaleme alın bu eser ${ }^{81}$, Osmanlı döneminde Mehmed Şevkî (ö. 957/1550 civarı) tarafindan Menâkıb-ı Eb̂̂ İshâk-ı Kâzerûnî adıyla kısaltılarak Türkçeye çevrilmiştir ${ }^{82}$. Bu tercüme Fatih Bayram tarafindan yeni harflere aktarılarak yayınlanmıştır ${ }^{83}$.

\section{Hâcû-yi Kirmânî (ö. 753/1352), Kemâlnâme}

Hâcû-yi Kirmânî İran'ın Kirmân şehrinde doğmuş, önce Kâzerûniyye (Mürşidiyye) tarîkatından Emînüddin Kâzerûnî’ye, sonra Kübreviyye tarikatından Alâüddevle Simnânî’ye mürid olmuş bir mutasavvıf ve şâirdir. Tasavvufî ve ahlâkî bir mesnevî olan Kemâlnâme isimli Farsça manzum eserini h. 744'te (1343) yazmıştır ${ }^{84}$. Eser, Osmanlı döneminde Emîrî diye bilinen Mehmed b. Musa Paşa (ö. 1005/1595’ten sonra) tarafindan Ahlâk-ı Kâmilîn adıyla Türkçeye çevrilmiştir ${ }^{85}$.

78 Kânpûr'da 1275 'te (1858) neşredilen Ma'mûlât-ı Mazhariyye isimli eserin sonunda ek olarak basılan eserin adı Mahbûbu'l-ârifín olarak kaydedilmiştir (s. 149-154). Delhi'de 1308 (1891)'de Resâil-i Sitte-i Zarûriyye adlı mecmua içindeki neşirde ise eser ismi kaydedilmemiş olup Risâle-i Şerîfe-i Hâce Azîzân Ali Râmîtenî şeklindedir (s. 9-14). Farsça eserin yazma bir nüshası: İstanbul Üniversitesi Ktp., Farsça Yazmalar, nr. 957, vr. 13b-17a.

79 Mustafa Kara, "Hocazâde Ahmed Hilmi”, Diyânet İslam Ansiklopedisi, İstanbul 1998, c. 18, s. 207.

80 Hocazâde Ahmed Hilmî, "Hoca Azîzân Ali Râmîtenî Hazretlerinin Risâle-i Şerîfesi Tercümesi”, Cerîde-i Sûfiyye, sy. 60 (1331/1913), s. 130-131; sy. 61 (1331/1913), s. 143-145.

81 Mahmûd b. Osmân, Firdevsü 'l-mürşidiyye fì esrâri'ş-șamediyye (nşr. Fritz Meier, Leipzig 1948; nşr. Îrec Efşâr, Tahran 1358 hş./1979). Bu eser, Hatîb Ebû Bekir'in (ö. 502/1109) Kâzerûnî’nin hayatı hakkında kaleme aldığı ve şimdi kayıp olan Arapça eserinin Farsça tercümesidir.

82 Süleymaniye Ktp., Esad Efendi, nr. 2429 (106 varak); Süleymaniye Ktp., Ömer Fazıl Aköz bölümü, nr. 17.

83 Şevkî Çelebi, Menâkıb-ı Ebû İshâk-ı Kâzerûnî (hzr. Fatih Bayram), İstanbul: Türkiye Yazma Eserler Kurumu Başkanlığı Yayınları, 2016.

84 Hâcû-yi Kirmânî, Kemâlnâme, Nuruosmâniye Ktp., nr. 3773, vr. 38b vd. Bkz. A. Naci Tokmak, "Hâcû-yi Kirmân̂̂”, Diyanet İslam Ansiklopedisi, İstanbul 1996, c. 14, s. 520-521.

85 Emîrî, Ahlâk-ı Kâmilîn, İsveç, Uppsala Üniversitesi Ktp., O Vet 63, vr. 176b-229a. Bkz. İsmail Güleç- Güler Doğan Averbek, "Gölgede Kalmış Bir Şairin Bilinmeyen Üç Tercümesi”, Dil ve Edebiyat Araştırmaları, sy. 18 (Güz 2018), s. 247-264. 


\section{İbn-i Bezzâz Erdebîlî (Dervîş Tevekkülî, ö. 759/1358'den son- ra), Safvetü's-safâ}

Safeviyye tarîkatının kurucusu Safiyyüddin Erdebîlî’nin (ö. 735/1334) söz ve menkıbelerini ihtivâ eden Safvetü's-safâ (diğer adıla el-Mevâhibü's-seniyye fì menâkıbi 's-Safeviyye) h. 759 (1358) senesinde Dervîş Tevekkülî adıyla da anılan İbn-i Bezzâz Erdebîlî tarafindan Farsça olarak kaleme alınmıştır ${ }^{86}$. Eserin dördüncü bölümü Osmanlı döneminde Anadolu'da veya İran'da birkaç defa Türkçeye tercüme edilmiştir. İlk tercüme Bedr isimli bir kişiye âit olup Safeviyye'den Şeyh Cüneyd'in mürşidliği döneminde $861 / 1456$ 'dan önce yapılmıştır. Kâşifu'l-kulûb adıyla da anılan bu tercüme yeni harflere çevrilerek yayınlanmıştır ${ }^{87}$. Eserin dördüncü bölümünün Tercüme-i Menâkıb-ı Şeyh Safiyyüddin veya Makâlât-ı Şeyh Safi adında başka çevirileri de vardır ${ }^{88}$. Ayrıca eser, bütününden ancak bazı kısaltmalarla, 949 (1543) senesinde Şirazlı Âzerî Türkü olan Muhammed Kâtib Neşâtî tarafından da Türkçeye çevrilmiş ve bu çeviri yayınlanmıştır ${ }^{89}$. Safvetü 's-safâ'nın Farsça metni Serap Şah tarafından doktora tezi içinde modern Türkçeye de çevrilmiştir ${ }^{90}$.

\section{Ahmed Eflâkî (ö. 761/1360), Menâkıbu'l-ârifîn}

Mevlânâ Celâleddin Rûmî'nin ve çevresindeki bazı zevâtın söz ve menkıbelerini ihtivâ eden Farsça Menâkıbu'l-ârifîn, Osmanlı döneminde Zâhid b. Ârif tarafindan 803 (1400) senesinde Mahzenü'l-esrâr adıyla, Gevrekzâde Hasan tarafından 1795'te Tercüme-i Menâkıbu'l-ârifîn adıyla, Abdülbâki Nâsır Dede tarafindan 1797'de Tercüme-i Menâkıbu'l-ârifîn (veya Tercüme-i Eflâkî) adıyla Türkçeye çevrilmiştir ${ }^{91}$. Eser, Kemâl Ahmed Dede (ö. 1024/1615 ?) tarafindan da muhtasar olarak ve nazmen Türkçeye çevrilmiştir ${ }^{92}$.

\footnotetext{
86 İbn-i Bezzâz Erdebîlî, Safvetü 's-safâ (nşr. Gulâm Rizâ Tabâtabâî Mecd), Tebrîz 1373 hș./1994.

87Şeyh Safiyeddin Erdebîlî, Makâlât: Şeyh Safí Buyruğu (nşr. Sönmez Kutlu- Nizamettin Parlak), İstanbul: Horasan Yayınları, 2008.

88 Tercüme-i Menâkıb-ı Şeyh Safiyyüddin, Süleymaniye Ktp., Hacı Mahmud, nr. 2642 (154 varak); Hacı Selim Ağa Ktp, Kemankeş, nr. 412 (140 varak), nr. 247 (137 varak). Bu son nüshanın yayını için bkz. İbn Bezzaz- Vehhab Rahman, Makâlât-ı Şeyh Safí (Safvetu's-safâ 4. Bab), Ankara: Alevi Akademisi Yayınları, 2009. Ayrıca bkz. Namiq Musalı, "Şeyh Safi Velâyetnâmesi: Tahkiki ve Transkripsiyonu", Türk Kültürü ve Hacı Bektaş Veli Araşsırma Dergisi, sy. 84 (2017), s. 166-168.

89 Muhammed Kâtib Neşâtî, Şeyh Safî Tezkiresi (hzr. Möhsün Nağısoğlu, Sever Cabarlı, Rauf Şeyhzamanlı), Bakü: Nurlan, 2006; Muhammed Kâtib Neşâtî, Tezkire-i Şeyh Safí: İnceleme Metin Dizin (hzr. Feyza Tokat), Ankara: Grafiker Yayınları, 2017 (2 cilt). Eser, Eski Anadolu, Âzerî ve Çağatay Türkçesinin izlerini taşımaktadır.

90 Serap Şah, Safvetü s-safầ 'da Safiyyüddîn-i Erdebîlì'nin Hayatı Tasavvufí Görüşleri ve Menkıbeleri, Marmara Ün. Sosyal Bilimler Enstitüsü, Dr. Tezi, İstanbul 2007.

91 Tahsin Yazıcı, "Menâkıbü'l-ârifîn", Diyanet İslam Ansiklopedisi, İstanbul 2004, c. 29, s. 114-115.

92 Kemâl Ahmed Dede, Tercüme-i Menâkıb-ı Mevlânâ, Süleymaniye Ktp., Hâlet Efendi Mülhakı, nr. 82 (158 varak). Betül Sinan Nizam, Kemâl Ahmed Dede’s Verse Narrative Tercüme-i Menâkıb-ı Mevlânâ (A Verse Version in the Menâkıbü'l-Arrifin Tradition), Cambridge, Harvard Üniversitesi, 2010.
} 


\section{Hâfız-ı Şîrâzî (ö. 792/1390 ?), Dîvân}

Hâfız-1 Şîrâzî’nin Farsça Dîvân’1 meşhurdur. Osmanlı döneminde Sûdî Bosnevî tarafından Şerh-i Dîvân-1 Hâfız-1 Şîrâzî (Bulak 1250) adıyla Türkçeye tercüme ve şerh edilmiştir. Sûdî’nin bu şerhi, İsmet Settârzâde tarafindan Şerh-i Sûdî ber Hâfız adıyla Farsçaya çevrilip neşredilmiştir (Tahran 1342-1347 hş./ 1964-1969). Ayrıca Konyalı Eş’arîzâde Mehmed Vehbi Efendi (ö. 1244/1828) de Hâfız'ın şiirlerini tasavvufî bir görüşle şerhetmiştir (Şerh-i Dîvân-1 Hâfız, Bulak 1273; I-II, İstanbul 1286, 1288-1289) ${ }^{93}$.

\section{Muhammed Pârsâ (ö. 822/1420), Risâle-i Kudsiyye; Faslü'l- hitâb; Risâle-i Keş̧fiyye.}

Risâle-i Kudsiyye: Nakşbendiyye tarikatına mensup Buharalı Muhammed Pârsâ'nın (ö. 822/1420), şeyhi Bahâeddîn Nakşbend'in sohbetlerinde tuttuğu notlar1 bilâhare şerh etmesiyle meydana getirdiği Farsça bir eserdir. İçinde zikir, telvîn, temkîn, cem, fark, velâyet, fenâ ve bakâ gibi tasavvufî konular bulunmaktadır. Ahmed Tâhirî Irâkî (Tahran 1975) ve Melik Muhammed İkbâl (Râvelpindî 1975) tarafindan tahkikli olarak neşredilen eser, Osmanlı döneminde Abdullah Salâhî Uşşâkî (ö. 1196/1782) tarafindan Türkçeye çevrilmiş ve neşredilmiştir (İstanbul 1323/1905).

Faslü'l-hitâb bi-vasli'l-ahbâb: Muhammed Pârsâ'nın Fenâ, bekâ, fütüvvet, tevhîd, müşâhede, ricâl-i gayb, ashâb ve Ehl-i beyt'e muhabbet konularını ihtivâ eden Farsça bir eserdir. İçinde uzun Arapça alıntılar olduğu için Arapça-Farsça karışımı hâline gelen eser önce tahkiksiz olarak (Taşkent 1331/1913) sonra Celîl Misgernijâd'ın tahkikiyle (Tahran 1381 hş./2003) neşredilmiştir. Faslü'l-hitâb Osmanlı döneminde Mûsâ b. Hacı Hüseyin İznîkî (ö. 838/1434) ve Tâhir b. Nebî Ruhâvî (XII/XVIII. asır) tarafindan iki defa Osmanlı Türkçesine tercüme edilmiştir ${ }^{94}$.

Risâle-i Keşfiyye: Zikir, Hakîkat-1 Muhammediyye, kelime-i tevhîd, aşk, marifet, tevhîd, tecellî ve vahdet-i vücûdla ilgili Farsça bir eserdir ${ }^{95}$. Osmanlı

93 Osman Sacid Arı, Mehmed Vehbi Konevi'nin Hafiz Divanı Şerhi'nde Tasavvufi Unsurlar, İstanbul Ün. Sosyal Bilimler Enstitüsü, Dr. Tezi, İstanbul 2016.

94 bkz. İznîkî için bk. İsmâil Paşa, Hediyyetü 'l-ârifin, II, 480; Mehmed Tâhir, Osmanlı Müellifleri, İstanbul 1333/1915, II, 13-14. İznîkî tercümesinin bir nüshası: İstanbul Ün. Ktp., TY, nr. 1543’te ve 261 varaktan müteșekkildir. Edisyon kritiği de yapılan bu tercüme henüz neşredilmemiştir: Murat Küçük, Mûsâ b. Hacı Hüseyin İznikî Terceme-i Faslu'l-hitâb-Giriş Inceleme Metin Dizin, YÖK Ktp., [Ankara] nr. 51599. Faslü'l-hitâb Tâhir b. Nebî Ruhâvî tarafindan da Türkçe'ye çevrilmiştir. Bk. Mehmed Tâhir, age, III, 83. İstanbul'da Âtıf Efendi Kütüphânesi'ndeki mütercimi kayıtlı olmayan ancak İznîkî tercümesinden farklı olan Faslü'l-hitâb tercümesi Ruhâvî’ye ait olabilir (Âtıf Efendi Ktp., Âtıf Efendi blm., nr. 1388).

95 Bir nüshası için bk. Süleymaniye Ktp., Pertev Paşa, nr. 616, vr. 142b-148a. 
döneminde Abdullah Salâhî Uşşâkî Efendi tarafından Risâle-i Vücûd Tercümesi adıyla Türkçeye çevrilmiştir ${ }^{96}$.

\section{Salâh b. Mubârek Buhârî (ö. 9./15. asır), Enîsü 't-tâlibîn ve Uddetü's-sâlikîn}

Salâh b. Mubârek Buhârî Bahâeddin Nakşbend'in sohbetlerinde bulunmuş $^{97}$, onun vefatından sonra halifesi Alâeddin Attâr'ın (ö. 802/1400) sohbetlerine devam etmiş bir Nakşbendî mensubudur. Bahâeddin Nakşbend'in menkıbelerini Enîsü't-tâlibîn adıyla Farsça olarak derlemiştir. Eserin Halil İbrahim Sarığlu tarafından tahkikli neşri de yapılmıştır (Tahran 1371 hş./1992). Eser, Osmanlı döneminde Süleyman İzzî Teşrîfâtî (ö. 1168/1755) tarafından Türkçeye tercüme edilmiş ve bu çeviri neşredilmiştir (İstanbul 1328/1910).

\section{Ya'kûb Çerhî (ö. 851/1447), Risâle-i Ünsiyye.}

Risâle-i Ünsiyye Nakşbendiyye tarîkat âdâbını konu alan Farsça bir eserdir. Müellif Ya'kûb Çerhî, Bahâeddîn Nakşbend'e intisap edişini ve Nakşbendiyye tarîkat silsilesini kaydettikten sonra, abdestli bulunmanın fazîleti, hafî zikrin fazîleti ve nâfile namaz konularını müstakil bölümlerde ele alıp anlatmış, son bölüm olan hâtimede ise Bahâeddîn Nakşbend ve Alâeddîn Attâr'ın bazı hikmetli sözlerini nakletmiştir. Muhtelif yazma ve matbu nüshaları bulunan eser ${ }^{98}$, Osmanl1 döneminde Nakşbendî-Müceddidî ve Melâmî şeyhi La'lîzâde Abdülbâkî Efendi (ö. 1159/1746) tarafından Türkçeye çevrilmiştir ${ }^{99}$.

Ya'kûb Çerhî'nin Tefsîr-i Ya'kûb Çerhî isimli Farsça eseri, Fâtiha sûresi ile Kur'ân'ın son iki cüzü üzerine yapılmış olup birkaç defa neşredilmiştir ${ }^{100}$. Bu

\footnotetext{
96 Süleymaniye Ktp., Pertev Paşa, nr. 633, vr. 77b-94b. Yeni harfli neşri için bkz. Semih Ceyhan, Abdullah Salâhî Uşşâkî ve Vücûd Risâleleri, Marmara Ün. Sosyal Bilimler Ens., YL Tezi, İstanbul 1998.

97 Salâh b. Mubârek h. 785 senesinde Alâeddîn Attâr vâsıtasıyla Bahâeddîn Nakşbend'in sohbetlerine gitmeye başladığını söyler. Bkz. Salâh b. Mubârek Buhârî, Enîsü t-tâlibîn ve uddetü s-sâlikîn (nşr. Halil İbrahim sarıoğlu), Tahran 1371 hş./1992, s. 66.

98 Farsça yazma nüshalarından biri: Süleymaniye Ktp., Şehid Ali Paşa, nr. 1386, vr. 2b-14a. İlk kez Muhammed Mahbûb Ali tarafindan Resâil-i Sitte-i Zarûriyye içinde tahkiksiz olarak neşredilmiş (Delhi 1308/1891, s. 15-37), daha sonra Muhammed Nezîr Rânchâ tarafından tahkik, tahric ve Urduca tercümesiyle birlikte yayınlanmıştır (İslâmâbâd 1983). 99 Ya'kûb Çerhî, Tercüme-i Risâle-i Ünsiyye (trc. La‘lîzâde Abdülbâkî), Süleymaniye Ktp., Pertev Paşa, nr. 636, vr. 227b-242b; Süleymaniye Ktp., Nafiz Paşa, nr. 446, vr. 116a-131b. Eser ayrıca, 1008 (1599) tarihinde Nakşbendî şeyhi Mudurnulu Şa ‘bân Efendi’nin (ö. 1002/1593) mürîdi Bâlî Alizâde İbrâhîm b. Muhammed Sîvâsî tarafından bazı kısaltma ve ilâvelerle tercüme edilmiş ise de, bu tam ve sağlıklı bir tercüme sayılamaz (Süleymaniye Ktp., Esad Efendi, nr. 3702, vr. 159b-177b).

100 Leknev 1308/1890; Bombay 1326/1908.
} 
eserin Osmanlı döneminde Gurâbzâde Ahmed b. Abdullah (ö. 1099/1688) tarafindan h. XI. (m. XVII.) asırda Osmanlı Türkçesine çevrildiği iddia edilmiş ise de ${ }^{101}$, Gurâbzâde, Zübedü âsâri'l-Mevâhib ve'l-envâr isimli tefsirinin başında bu eserini hazırlarken Ya'kûb Çerhî, Beyzâvî ve Hüseyin Vâiz Kâşifi’’nin eserlerinden yararlandığını söylediğine göre ${ }^{102}$, bu eser tam bir tercüme sayılamaz.

\section{Ubeydullah Ahrâr (ö. 895/1490), Fıkarât, Risâle-i Havrâiyye, Risâle-i Vâlidiyye.}

Nakşbendî şeyhlerinden olan Ubeydullah Ahrâr Taşkent’te doğmuş, Semerkand'da vefat etmiştir.

Fıkarât: Tevhîd, fenâ, kurb, tecellî zikir ve vukûf-i kalbî gibi konulara dâir Farsça bir eserdir. Kütüphanelerde birçok yazma nüshası bulunan eser, birkaç defa neşredilmiş ${ }^{103}$ son olarak Ârif Nevşâhî tarafından Resâil-i Hâce Ahrâr isimli mecmua içinde yayınlanmıştır (Herât: İntişâât-1 Ahrârî, 2015). Flkarât, Osmanlı döneminde Hızır Bey $(924 / 1518)^{104}$ ve Mustafa b. Hüseyin Sâdıkî Nakşbendî1 ${ }^{105}$ tarafından Türkçeye tercüme edilmiştir.

Risâle-i Havrâiyye (ya da Şerh-i Havrâiyye): Ebû Sa'îd-i Ebu'l-Hayr'ın "Havrâ" (hûriler) kelimesiyle başlayan rubâîsinin şerhi olup Farsçadır. Ubeydullah Ahrâr, bu rubâînin bazı hastaların yanında okununca onları iyileştirdiğini duymuş, onun manalarını araştırmaya başlamış ve rubâîyi şerh ederek bu eserini meydana getirmiştir. Kütüphanelerde birçok yazma nüshası olan eser ${ }^{106}$, birkaç

\footnotetext{
101 Mehmed Tâhir, Osmanlı Müellifleri, İstanbul 1333/1915, I, 239-240.

102 Gurâbzâde Ahmed, Zübedü âsâri 'l-Mevâhib ve'l-Envâr, İstanbul 1292-1294, c. 1, s. 3-4. (Bu eser, Fâtiha'dan Nâs'a kadar tam tefsirdir).

103 Taşkent’te (Taşkent 1910) ve Hindistan'ın Haydarâbâd şehrinde neşredilmiştir (Haydarâbâd ts., Matba-1 Âyîn-i Dekken).

104 Hızır Bey, Tercüme-i Külliyyât-ı Hâce Ubeydullâh-i Ahrâr adıyla Ahrâr'ın Risâle-i Vâlidiyye, Şerh-i Havrâiyye ve Flkarât adlı eserlerini Türkçe'ye çevirmiştir. Süleymaniye Ktp., Bağdatlı Vehbi, nr. 2047, vr. 148a-155a (Risâle-i Vâlidiyye), vr. 155a-158b (Şerh-i Havrâiyye), vr. 158b-222a (Fıkarât). Bu tercümenin sonunda mütercim olarak Mevlânâ Hızır Bey'in ismi kaydedilmiştir. İstanbul'un ilk kadısı olan Mevlânâ Hızır Bey’in 863 (1459) senesinde vefat ettiği, Flkarât'ın ise en erken 890 senesinde yazıldığı düşünülürse mütercimin bu zât olamayacağı ortaya çıkar. Ancak bazı araştırmacılar nüshanın sonundaki kayda bakarak tercümeyi ona izâfe etmişlerdir (bk. Mustafa Said Yazıcıŏlu, "Hızır Bey", Diyanet İslam Ansiklopedisi (DIA), XVII, 414). Mütercim, muhtemelen Mevlânâ Hızır Bey'in torunu ve Nakşbendî şeyhi Emîr Ahmed Buhârî'nin halifelerinden olan Hızır Bey (Çelebi) b. Ahmed Paşa b. Mevlânâ Hızır Bey'dir (ö. 924/1518). Hayatı için bk. Mecdî Mehmed, Hadâiku'ş-Şakâik, İstanbul 1269/1853, s. 431.

105 Bu zât, Hâce Ahmed Sâdık Tâşkendî Nakşbendî’nin (ö. 994/1586) mürîdi ve padişah’ın husûsî imamı idi. Rabî‘u'l-âhir 1018 'de (1609) Fıkarât Tercemesi'ni tamamlamıştır (bazı nüshaları: Süleymaniye Ktp., Reşid Efendi, nr. 362, vr. 1b-151a; Süleymaniye Ktp., Ali Nihat Tarlan, nr. 63, vr. 1b-75b). Bazı kütüphaneciler bu zâtı, Muslihuddîn Mustafa Nakşbendî (ö. 1068/1658) ile karıştırıp kataloglara onun ismiyle kaydetmişlerdir.

106 Meselâ: Süleymaniye, Esad Efendi, nr. 1688, vr. 114b-118a; Millet Ktp., A.E.Fârsî, nr. 77, vr. 142b-146a.
} 
defa neşredilmiştir ${ }^{107}$. Eser, Osmanlı döneminde Hızır Bey tarafından Türkçeye çevrilmiş̧itir ${ }^{108}$.

Risâle-i Vâlidiyye: Babası, Ubeydullah Ahrâr'dan yüksek mânevî makamlara ulaşmaya sebep olacak hususları yazmasını istemiş, Ahrâr da bu talep üzerine bu küçük Farsça eseri kaleme almıştır. Eserde ibâdet, mârifetullah, Hz. Peygamber'e uymak, zikir ve Allah sevgisi gibi konular ele alınmaktadır. Birçok yazma nüshası bulunan eser ${ }^{109}$, Ârif Nevşâhî tarafindan neşredilmiştir ${ }^{10}$.

Risâle-i Vâlidiyye Osmanlı döneminde Hızır Bey (ö. 924/1518), Mehmed Emîn Tokâdî (ö. 1158/1745) ${ }^{111}$, Mehmed Rif at Kâdirî (ö. 1269/1853) ${ }^{112}$ ve Harputlu Beyzâde Ali Efendi (ö. 1322/1904) ${ }^{113}$ tarafindan Osmanlı Türkçesi’ne çevrilmiştir.

\section{Abdurrahmân Câmî (ö. 898/1492), Nefahâtü'l-üns, Levâyih, Levâmi', Şerh-i Rubâiyyât, Bahâristân.}

Herât'ta yaşamış olan Abdurrahman Câmî, Nakşbendî şeyhlerinden Sa'deddin Kâşgarî’nin müridi ve halifesidir.

Nefahâtü'l-üns min hazarâti'l-kuds: Kendi dönemine kadar yaşayan meşhur sûfîlerin söz ve menkıbeleri ile bazı tasavvufî̀ 1stılahları açıklayan Farsça bir eserdir. Ali Şîr Nevâî tarafindan Nesâyimü'l-mahabbe adıyla Çağatay Türkçesine çevrilen eser, Osmanlı sahasında bazı ilâveler yapılarak iki defa Türkçeye çevrilmiştir. Bursalı Lâmi‘î Çelebi diye bilinen Mahmûd b. Osman (ö. 933/1532) tarafindan bazı Osmanlı mutasavvıfları ve Câmî’nin terceme-i hâli gibi ilâveler yapılarak Fütûhu'l-mücâhidîn li-tervîhi kulûbi'l-müşâhidîn adıyla tercüme edilip neşredilmiştirir ${ }^{14}$. Hacı Ali Efendi Tosyavî tarafından 1084/1674

\footnotetext{
107 İlk kez Valentin Jukovski tarafindan Esrâru 't-tevhîd fì makâmâti'ş-Şeyh Ebî Sa 'îd adlı eserin ekinde (St. Petersburg 1899, s. 488-493), daha sonra da Sa ‘îd Nefîsî tarafindan Sühanân-ı Manzûm-i Ebû Sa î̀d-i Ebu'l-Hayr adlı eserin içinde (Tahran ts. s. 126-131) neşredilmiştir. Son olarak Ârif Nevşâhî tarafindan Resâil-i Hâce Ahrâr (Herat 2015) içinde neşredilmiștir.

108 Süleymaniye Ktp., Bağdatll Vehbi, nr. 2047, vr. 155a-158b.

109 Meselâ: Millet Ktp., A.E.Fârsî, nr. 77, vr. 50b-57b.

110 Ârif Nevşâhî, "Risâle-i Vâlidiyye-i Ubeydullâh-i Ahrâr-i Semerkandî", Tahkîkât-ı İslâmî, IX/1-2 (1373/1994), s. 65-

77. Ayrıca Resâil-i Hâce Ahrâr (Herat 2015) içinde yayınlanmıştır.

$111 \mathrm{Bu}$ tercüme 1135 'te veya 1136 'da (1723-24) yapılmıştır. Süleymaniye Ktp., Reşid Efendi, nr. 362, vr. 151b-163a; Millet Ktp., Ali Emîrî Şer'iyye, nr. 832, vr. 35b-41b. Mütercim için bk. Hüseyin Vassâf, Sefine-i Evliyâ, II, 34-44. 112 Süleymaniye Ktp., Yazma Bağışlar, nr. 4342, vr. 13b-27a. Esâsen tercüme 20a varağında biter, bundan sonra mütercim bazı Kādirî şeyhleri hakkında kısa bilgiler vererek eseri sürdürür.

113 Beyzâde Ali Efendi'nin diğer eserleriyle birlikte mecmuanın sonunda neşredilmiştir (İstanbul 1276/1859), s. 1-8. Mütercim için bk. İsmet Sunguroğlu, Harput Yollarında, II, 110 vd.; Abdurrahman Memiş, Hâlid-i Bağdâdî ve Anadolu'da Hâlidîlik, İstanbul 2000, s. 197-8.

114 İstanbul 1289/1872.
} 
senesinde Tuhfetü'l-mücâhidîn ve behcetü'z-zâkirîn adıla yine ilaveli olarak tercüme edilmiştir ${ }^{15}$.

Levâyih: Vahdet-i vücûdla ilgili konuların ele alındığı bir eserdir. Bu Farsça mensûr eser Osmanlı döneminde Şemseddin Sivasî (ö. 1006/1597) tarafindan es-Safâyı fí-Tercemeti'l-Levayıh adıyla Türkçeye tercüme edilmiştir. Bu tercüme Melek Gündüz Karacan tarafından yeni harflere çevrilip neşredilmiştir ${ }^{116}$. Câmî’nin Levâyih isimli Farsça eserini ayrıca h. 989'da (1581) Abdülmecîd b. Şeyh Nasûh Tosyavî (ö. 996/1588) de Türkçeye tercüme etmiştir ${ }^{117}$.

Levâmi‘: İbnü'l-Fârız'ın (ö. 632/1235) Arapça Kasîde-i Hamriyye'sinin Farsça tercüme ve şerhidir. Eser, Îrec Efşâr tarafindan Tahran'da neşredilmiştir (Levâmi 've Levâylh, Tahran 1360/1981). Levâmi', Tâhirü'l-Mevlevî (ö. 1951) tarafindan Osmanlı Türkçesine tercüme edilmiştir ${ }^{118}$.

Şerh-i Rubâiyyât: Abdurrahmân Câmî tarafindan nazm edilen rubâilerin, yine Câmî tarafindan yapılan şerhlerinden oluşan Farsça bir esedir. Konusu vahdet-i vücûd ve Nakşbendiyye tarikatındaki onbir esastır. Eser, Osmanlı son döneminde Tâhirü'l-Mevlevî tarafından 1927'de Türkçeye tercüme edilmiştir. Bilinen tek nüshası Marmara Üniversitesi İlahiyat Fakültesi Kütüphanesi'nde (Yazmalar, nr. 21, s. 206-266) bulunan tercüme Abdurrahman Acer tarafından yeni harflere çevrilerek neşredilmiştitir ${ }^{119}$.

Bahâristân: Câmî'nin Bahâristân isimli Farsça eseri Üsküdarlı Şem'î Efendi (ö. 1011/1602) tarafından tercüme ve şerh edilmiştir. Şerh-i Bahâristân adıyla Sadrazam Sokullu Mehmed Paşa adına kaleme alınan eserin çeşitli kütüphanelerde nüshaları vardır ${ }^{120}$. Şerh-i Bahâristân üzerine Davut Akat yüksek lisans çalışması yapmıştır ${ }^{121}$.

115 Nuruosmaniye Ktp., nr. 2293 (624 varak). Köstendilli Süleyman Şeyhî Efendi'nin (ö. 1235/1819) Bahru'l-velâye isimli Türkçe eserinin temel kaynaklarından biri de Nefahâtü'l-üns'tür.

116 Molla Câmî, Seyr u Sülûk ve Vahdet-i Vücûda Dâir Levâyih (trc. Şemseddin Sivasî, hzr. Melek Gündüz Karacan), İstanbul: Litera Yayınc1lık, 2016.

117 Abdülmecîd Tosyavî (trc.), Tercümetü 'l-Levâyih, Kastamonu İl Halk Ktp., nr. 36, vr. 221b-230b. Mütercimin hayatı ve eserleri için bkz. Ufuk Hayta, Abdülmecîd b. Nasûh Tosyevî'nin (ö. 1588) Hayatı Eserleri ve el-Hüdâ ve'l-Felâh Adlı Tefsir Risalesinin Tahkiki, Uludağ Üniversitesi Sosyal Bilimler Enstitüsü, 2008.

118 Abdurrahman Câmî, Levâmi' Tercümesi (trc. Tâhirü'l-Mevlevî), Marmara Ün. İlahiyat Fakültesi Ktp., Yazmalar, nr. 21, s. 64-205.

119 Molla Câmî, Şerh-i Rubâiyyât (trc. Tâhiru'l-Mevlevî, hzr. Abdurrahman Acer), İstanbul: Litera Yayıncılık, 2014. 120 Süleymaniye Ktp., Servili, nr. 232, Lala İsmâil Paşa, nr. 522; Ankara TDK Ktp., TY, nr. A 78.

121 Davut Akat, Şem'î: Şerh-i Bahâristân. Giriş- Metin, Uludağ Üniversitesi Sosyal Bilimler Enstitüsü, YL tezi, Bursa 1999. Şeyda Öztürk, "Şem' ̂̂", Diyanet İslam Ansiklopedisi, İstanbul 2010, c. 38, s. 503-504. 
Muhammed Kâdî Semerkandî (ö. 921/1515), Silsiletü'l-ârifîn ve tezkiretü's-sıddîkîn

Muhammed Kâdî Semerkandî, Nakşbendî şeyhlerinden Ubeydullah Ahrâr'ın müridi ve halifesidir.

Silsiletü'l-ârifin ve tezkiretü's-sıddîkîn: Eser, bir Mukaddime, üç Fasıl ve bir Hâtime'den oluşur. Mukaddime, Hak Teâlâ'yı tanımak ile mürîdliğin ve şeyhliğin âdâbı konularına dâirdir. 1. Fasıl, Ubeydullah Ahrâr'1n ilk hallerini; 2. Fasıl, sohbetlerinde anlattığı hakîkatleri ve incelikleri; 3. Fasıl, kerâmetlerini, Hâtime de ilk dönem sûfîlerinin ahlâk ve hikâyelerini ihtivâ etmektedir. Muhtelif yazma nüshaları bulunan eser $^{122}$, Tahran'da neşredilmiştir ${ }^{123}$. Eserin küçük bir bölümü, Osmanlı döneminde La'lîzâde Abdülbâkî Efendi (ö. 1159/1746) tarafından Türkçeye çevrilmiştir ${ }^{124}$.

\section{Hilâlî-i Çağatâyî (ö. 936/1529), Sıfâtü 'l-âşıkîn}

Aşkın mâhiyeti ve sadâkat, vefâ, cömertlik, cesâret, alçak gönüllülük, edep gibi konuların işlendiği yirmi bölümden meydana gelen Farsça bir mesnevi olan Sıfâtü'l-âşıkîn'in her bölümünde konular birer küçük hikâye ile açıklanmış$\operatorname{tır}^{125}$. Bu eser Osmanlı döneminde Emîrî diye bilinen Mehmed b. Musa Paşa (ö. 1005/1595'den sonra) tarafından Türkçeye çevrilmiştir ${ }^{126}$.

\section{Fahreddin Ali b. Hüseyin Safî (ö. 939/1532), Reşahât-ı Aynü'l-hayât}

Fahreddin Ali Safî, Nakşbendî şeyhlerinden Ubeydullah Ahrâr'ın müridlerinden olup Herat'ta yaşamıştır.

Reşahât-ı Aynü'l-hayât, Safî lakabıyla anılan Fahreddin Ali b. Hüseyin Vâiz Kâşifî̀n nin kaleme aldığı Farsça bir eser olup Hâcegân ve Nakşbendî şeyhlerinin, özellikle de Ubeydullah Ahrâr'ın sözlerini ve menkıbelerini ihtivâ etmektedir. Ali Asgar Muîniyân tarafından tahkikli neşri yapılan eser (Tahran 1977)

122 Süleymaniye Ktp., Hacı Mahmud, nr. 2830, vr. 2a-209a (bu nüsha baştan 10 varak kadar eksiktir); Ahmed Münzevî, Fihrist-i Müşterek, İslâmâbâd-Lahor 1988, c. 11, s. 842-3.

123 Muhammed b. Burhâneddin Semerkandî, Silsiletü l-ârifin ve tezkiretü 's-sıddîkîn (nr. İhsânullah Şükrullâhî), Tahran: Kitâbhâne Mûze ve Merkez-i Esnâd-1 Meclis-i Şûrâ-yı İslâmî, 1388 hş./2009.

124 Süleymaniye Ktp., Pertev Paşa, nr. 636, vr. 246b-266b.

125 Farsça eserin yazma bir nüshası: Süleymaniye Ktp., Pertev Paşa, nr. 435. Bkz. H. Ahmet Sevgi, "Hilâlî-i Çağatâyî", Diyanet İslam Ansiklopedisi, İstanbul 1998, c. 18, s. 21-22.

126 Emîrî, Slfâtü 'l-âşıkîn, İsveç, Uppsala Üniversitesi Ktp., O Vet 63, vr. 235b-290b. Bkz. İsmail Güleç- Güler Doğan Averbek, "Gölgede Kalmış Bir Şairin Bilinmeyen Üç Tercümesi", Dil ve Edebiyat Araştırmaları, sy. 18 (Güz 2018), s. 255-256; İsmail Güleç- Güler Doğan Averbek- Turgay Şafak, Gönül Erlerinin Vasıflart: Emirî'nin Sıfâtü'l-âşskîn Tercümesi, İstanbul: Büyüyen Ay Yayınları, 2019. 
Osmanlı döneminde iki defa Türkçeye tercüme edilmiştir. İlk tercüme, Muhyî Gülşenî (ö. 1014/1605) tarafından 977 (1569) senesinde kaleme alınan ve Zincîr-i Zeheb ya da Reşahât-ı Muhyî adıyla bilinen eserdir. Osmanlı Türkçesi ile yazılan bu eser Reşahât' 'n bazen özet, bazen de ilâveli bir tercümedir ${ }^{127}$. Yeni harflere çevrilip yayınlanmıştır ${ }^{128}$. Reşahât'ın ikinci tercümesi, Ârifî nisbesiyle bilinen Trabzonlu Muhammed Ma'rûf b. Muhammed Şerîf (ö. 1002/1594) ${ }^{129}$ tarafindan 993 ’te (1585) yapılmıştır. Osmanlı döneminde birkaç kez neşredilmiştitir ${ }^{130}$.

\section{Abdülvehhâb Hemedânî Sâbûnî (ö. 954/1547), Sevâkıbu'l-menâkıb}

Abdülvehhâb Hemedânî Hemedan'da doğmuş, Kâhire'de bulunmuş, Medîne'de vefat etmiş bir Nakşbendî mensubudur ${ }^{131}$.

Sevâkıbu'l-menâkıb: Mevlânâ Celâleddin Rûmî'nin menkıbelerini ihtivâ eden Ahmed Eflâkî’ye (ö. 761/1360) âit Menâklbu'l-ârifin isimli Farsça eserin kısaltılmış ve dil yönünden düzeltilmiş bir şekli olan Sevâkıbu'l-menâkıb, Abdülvehhâb Hemedânî tarafindan 947 (1540) senesinde kaleme alınmıştır. Sevâkıb'in Farsça metni Ârif Nevşâhî tarafından Tahran'da neşredilmiştir ${ }^{132}$. $\mathrm{Bu}$ eser Osmanlı döneminde iki defa Türkçeye tercüme edilmiştir. İlk tercüme Dervîş Halîl Senâî (ö. 950/1543) tarafından muhtasar olarak yapılmış ve Kânûnî Sultan Süleyman'a takdim edilmiştir. Bu tercümenin Süleymaniye Kütüphanesi'nde (Hâlet Efendi İlâvesi, nr. 49 ve 50) iki nüshası mevcuttur. Sevâkıbu'l-menâkıb'ın ikinci tercüme ise Dervîş Mahmûd Mesnevîhân tarafından 998 (1590) senesinde yapılmış ve Sultan III. Murâd'a ithâf edilmiştir. Bu ikinci tercümenin çok sayıda yazma nüshaları vardır. Ayrıca Osmanlı dönemin-

\footnotetext{
127 Bu eserin bir nüshası İstanbul'da Yapı Kredi Sermet Çifter Araștırma Kütüphanesi, nr. 127'de (yeni nr. 302) kayıtl olup 296 varaktan müteşekkildir. Bu nüsha bizzat Muhyî Gülşenî tarafından 1013 (1604) senesinde istinsah edilmiştir. Eserin baş ve son taraflarında Muhyî'nin ilâveleri bulunmaktadır.

128 Muhyî-i Gülşenî, Reşehât-ı Muhyî (nşr. Mustafa Koç- Eyyüp Tanrıverdi), İstanbul: Türkiye Yazma Eserler Kurumu Başkanlığı Yayınları, 2014.

129 Hayatı için bk. Nev'îzâde Atâi, Hadâiku'l-hakâik, İstanbul 1268/1852, s. 327-328; Mehmed Tâhir, Osmanlı Müellifleri, II, 22.

130 Bulâk 1256/1840; İstanbul 1291/1874. Reşahât, Çağatay Türkçesine de Molla Hudaybergan tarafından tercüme edilmiştir. Bk. Necdet Tosun, Türkistan Dervişlerinden Yâdigâr, s.156-157.

131 Ali Alparslan, “Abdülvehhâb es-Sâbûnî”, Diyanet İslam Ansiklopedisi, İstanbul 1988, c. 1, s. 286-287.

132 Abdülvehhâb Hemedânî, Sevâkıbu 'l-menâkıb-l Evliyâullâh (nşr. Ârif Nevşâhî), Tahran: Merkez-i Pejûheşî-yi Mîrâs-1 Mektûb, 1390 hş./2011.
} 
de Müzekkî'n-nüfûs isimli eserin kenarında basılmıştır (İstanbul 1281) ${ }^{133}$. Eser yeni harflere de çevrilip yayınlanmıştır ${ }^{134}$.

\section{Muhammed b. Hüseyin Kazvînî (978/1570'ten sonra), Silsilenâme-i Hâcegân-ı Nakşbend}

Nakşbendiyye'nin Kâsâniyye koluna mensup olan Muhammed b. Hüseyin Kazvînî1 ${ }^{135}$ h. 978'de (1570) Şam'da Silsilenâme-i Hâcegân-ı Nakşbend isminde Farsça bir eser kaleme almış ve başlangıçtan kendi zamanına kadar gelen Nakşbendî şeyhleri hakkında kısa bilgiler vermiştir. Muhtelif yazma nüshaları olan $\operatorname{eser}^{136}$, Osmanlı döneminde Mustafa b. Hayreddin tarafindan Türkçeye tercüme edilmiştir ${ }^{137}$.

\section{İmâm-ı Rabbânî Ahmed Sirhindî (ö. 1034/1624), Mektûbât, Mebde've Me'âd}

İmâm-1 Rabbânî, Hindistan'da yaşamış bir Nakşbendî şeyhidir. Müceddid-i Elf-i Sânî lakabıyla anılır.

Mektûbât: İmâm-1 Rabbânî Ahmed Sirhindî’nin mürîdlerine ve dostlarına yazdığı toplam 536 mektuptan oluşan üç ciltlik Farsça bir eserdir. Bir çok baskısı olan Mektûbât Osmanlı döneminde Müstakîmzâde Süleyman Sa'deddîn Efendi (ö. 1202/1787) tarafindan h. 1162-1165 yılları arasında Farsçadan Türkçeye tercüme edilmiş ve daha sonra yayınlanmıştır (İstanbul 1277/1860).

Mebde' ve Me'âd: İmâm-1 Rabbânî’nin seyr u sülûk mertebeleri hakkında Farsça bir eserdir. Müellifin farklı zamanlarda yazdığı 61 parça yazısının, mürîdlerinden Muhammed Siddîk Bedahşî Kişmî (ö. 1050/1640) tarafindan 1019 (1610) senesinde derlenmesiyle oluşmuştur. Eser Delhi, Lahor ve Karaçi'de neşredilmiş ${ }^{138}$, İstanbul'da Karaçi neşrinin tıpkıbasımı yapılmışıı1 ${ }^{139}$. Mebde've

133 Ârif Nevşâhî, "Sevâkıbu'l-menâkıb-1 Evliyâullah: Mevlânâ ve Mevlevîlik Hakkında Unutulmuş Bir Kaynak”, (trc. Necdet Tosun), Tasavvuf: İlmî ve Akademik Araştırma Dergisi, sy. 14 (2005), s. 697-707.

134 Derviş Mahmud-1 Mesnevihan, Sevâkıb-ı Menâkıb (nşr. Hüseyin Ayan- Gönül Ayan- Erdoğan Erol), Konya: Rumi Yayınları, 2007.

135 Silsilesi: Ubeydullah Ahrâr, Muhammed Kâdî Semerkandî, Ahmed Kâsânî Dehbîdî, Muhammed İslâm Cûybârî, Mevlânâ Hüseyin Kazvînî (ö. 974 Şam), Muhammed b. Hüseyin Kazvînî (müellif).

136 Süleymaniye Ktp., Laleli, nr. 1381, vr. 1b-14; Süleymaniye Ktp., lala İsmail, nr. 155; Millet Ktp, A.E. Şer’iyye, nr. 1035.

137 Kazvînî, Silsile-i Hâcegân-ı Nakşbendiyye Tercümesi (trc. Mustafa b. Hayreddîn), Süleymaniye Ktp., Hüsrev Paşa, nr. 408 , vr. 1a-17a.

138 Mebde've Me 'âd, Delhi, Matba-i Ensârî, 1307/1889; Resâil-i Müceddidiyye (nşr. Mahbûb İlâhî), Lahor 1965, içinde, s. 57-140; Mebde've Me ‘âd, Karaçi, İdâre-i Müceddidiyye, 1968.

139 Mebde've Me 'âd, İstanbul, Hakîkat Kitabevi, 1994. 
Me âd Osmanlı döneminde Harputlu Beyzâde Ali Efendi (ö. 1322/1904) tarafindan Türkçeye tercüme edilmiş ve neşredilmiştir ${ }^{140}$.

\section{Muhammed Ma'sûm Sirhindî (ö. 1079/1668), Mektûbât-ı Ma'sûmiyye, Hasenâtü'l-Haremeyn}

Mektûbât: Muhammed Ma ‘sûm, İmâm-1 Rabbânî Ahmed Sirhindî’nin oğludur. Muhammed Ma'sûm'un mektupları üç cilt hâlinde derlenerek yayınlanmıştır (Mektûbât-ı Ma sûmiyye, Karaçi 1396/1976). Farsça olan bu mektuplar, Osmanlı döneminde Müstakîmzâde Süleymân Sa'deddîn Efendi (ö. 1202/1787) tarafından Türkçeye çevrilmiş ve neşredilmiştir (İstanbul 1277/1860).

Hasenâtü'l-Haremeyn: Muhammed Ma'sûm 1068 (1658) senesinde Hicâz'a gitmiş, orada nâil olduğu ilhâm ve keşifler oğlu Muhammed Ubeydullah tarafindan Hasenâtü'l-Haremeyn adıyla Arapça olarak derlenmiş, daha sonra Muhammed Şâkir b. Bedreddîn Sirhindî tarafindan Farsçaya çevrilmiştir. Bu Farsça nüsha Muhammed İkbâl Müceddidî’nin tahkîkiyle neşredilmiştir (Lahor 1981). Eser Osmanlı döneminde Müstakîmzâde Süleymân Sa'deddîn Efendi tarafindan Türkçeye çevrilmiştir ${ }^{141}$.

\section{Ebû Abdullah Muhammed Semerkandî (ö. 1116/1704), Muhtasaru'l-velâye}

Aslen Semerkandlı olduğu anlaşılan Ebû Abdullah Muhammed Semerkandî Hicâz'daki Nakşbendî-Müceddidî şeyhi Ahmed Yekdest Cûryânî’nin mürid ve halifesidir ${ }^{142}$. İstanbul'a gelip Üsküdar'ı Şemsi Paşa semtinde tekke şeyhliği yapmış ve 1116 (1704) senesinde vefat edip Karaca Ahmed Mezarlı̆̆ı'na defnedilmiştir ${ }^{143}$.

Muhtasaru'l-velâye isimli Farş̧a eserinde Allah'ın zâtı, sıfatları, marifetullah, Nakşbendiyye silsilesi ve âdâbı, zikir, teveccüh, murâkabe, râbıta gibi konular ele alınmıştır. Yazma nüshaları bulunan eserin metni yüksek lisans tezi olarak hazırlanmıştır ${ }^{144}$.

Muhtasaru'l-velâye Osmanlı döneminde Neccârzâde Şeyh Rızâ Efendi (ö. 1159/1746) tarafından Türkçeye tercüme edilmiştir. Birçok yazma nüshası olan

140 Risâle-i Celîle-i Mebde've Me âd (trc. Beyzâde Ali Harputî), Kastamonu 1290/1873.

141 Tercümenin nüshalarından biri için bk. Süleymaniye Ktp., Hacı Mahmud, nr. 2848, vr. 1b-27b.

142 Cûryânî'nin şeyhi Muhammed Ma'sûm Sirhindî’dir. Muhammed Ma'sûm'un şeyhi de İmâm-1 Rabbânî'dir.

143 Hüseyin Vassâf, Sefine-i Evliyâ (nşr. Ali Yılmaz- Mehmet Akkuş), İstanbul 2006, c. 2, s. 102.

144 Elif Namoğlu, Ebû Abdullah Muhammed es-Semerkandî'nin Muhtasaru'l-velâye Adlı Eseri (Metin-İnceleme), İstanbul Üniversitesi Sosyal Bilimler Enstitüsü, YL tezi, 2012. (Farsça metnin tahkîki ve Türkçe İnceleme şeklindedir). Farsça eserin bazı yazma nüshaları: Süleymaniye Ktp., Hacı Mahmud, nr. 2914 (53 varak); Millet Ktp., Ali Emîrî Frs., nr. 962 (vr. 11b-92a) 
bu tercüme ${ }^{145}$ Osmanlı döneminde neşredilmiştir ${ }^{146}$. Tercüme, yüksek lisan tezi olarak yeni harflere de aktarılmıştır ${ }^{147}$.

\section{Abdullah Nidâî Kâşgarî (ö. 1174/1760), Risâle-i Hakkıyye (veya Risâle-i Hafiyye).}

Kâşgar'da doğup İstanbul'da vefat eden Nakşbendî şeyhlerinden Abdullah Nidâî Kâşgarî’nin Risâle-i Hakklyye ${ }^{148}$ isimli Farsça eseri, Osmanlı döneminde

Edirne kadısı Mustafa İsâmeddin (ö. 1203/1789 ?) ${ }^{149}$ ve İsmail Müfîd Efendi ${ }^{150}$ tarafından iki defa tercüme edilmiştir.

\section{Burhâneddin Muhammed Nakşbendî (ö. 1212/1797'den sonra), Meslekü'l-envâr ve menbau'l-esrâr.}

Burhâneddin Muhammed Nakşbendî Orta Asya'da Semerkand civarında halkı irşâd eden Muhammed Sıddîk isimli Nakşbendî Müceddidî şeyhinin müridi ve halifesidir ${ }^{151}$. 18. Yüzyılda Orta Asya'dan İstanbul'a gelmiştir. Hayatı hakkında yeterli bilgi yoktur.

Burhâneddin Muhammed Nakşbendî İstanbul'a geldiğinde bazı tasavvufî 1stılahları, rüya tabiri konusunu ve Nakşbendî seyr u sülük usullerini ele alan Meslekü'l-envâr ve menbau'l-esrâr isminde Farsça bir eser kaleme almış ve bu eserini devrin sadr-1 a'zamı Mehmed İzzet Paşa'ya ${ }^{152}$ takdim etmiştir. Paşa, Farsça bilmeyenlerin de istifâde edebilmesi için bu eserin Türkçeye tercüme edilmesini arzu etmiş ve bu işi Hoca Süleyman Neş'et'e (ö. 1222/1807) havale etmiştir. Hoca Neş'et de 1212 (1797) senesinde bu eseri Türkçeye çevirmiştir. Farsça aslının

\footnotetext{
145 Meselâ: Süleymaniye Ktp., Hacı Mahmud, nr. 2470. 146 İstanbul: Matbaa-i Âmire, 1272/1855 (63 sayfa).

147 Ayşe Serra Kesikbaş, Muhtasaru'l-velâye Tercümesi (Metin ve İnceleme), Marmara Üniversitesi Sosyal Bilimler Enstitüsü, YL tezi, İstanbul 2011.

148 Güller Nuhoğlu, Abdullah Nidâ̂-yi Kâş̧garî ve Hakkıyye Risâlesi, İstanbul: Simurg Kitapç1lı, 2004.

149Abdullah Nidâî Kâşgarî, Risâle-i Hafiyye (trc. Edirne Kadısı Mustafa İsâmeddin), İstanbul Belediye Ktp., O.E.Yzm., nr. 919, vr. 1b-50b; Edirne Selimiye Yazma Eser Ktp, nr. 106/1. Mütercim, müellifin mürididir. Hayatı için bkz. Fuat Günel, "Üsküdârî, İsâmüddin”, Diyanet İslam Ansiklopedisi, İstanbul 2016, c. Ek-2, s. 640-641. https://islamansiklopedisi. org.tr/uskudari-isamuddin

150 Abdullah Nidâî Kâşgarî, Risâle-i Hakkıyye Tercümesi (trc. İsmail Müfîd Efendi), Süleymaniye Ktp., Esad Efendi, nr. 1422. (Tercüme tarihi: 1205/1790. Mütercim, müellifin mürididir).

151 Silsilesi: İmâm-1 Rabbânî Ahmed Sirhindî, Muhammed Sâ̂d Sirhindî, Abdülehad Vahdet Sirhindî, Muhammed Âbid Sünnâmî, Mûsâ Hân Hoca Dehbîdî, Muhammed Siddîk, Burhâneddin Muhammed Nakşbendî (müellif). Bu silsileyi müellif, eserinin baş tarafinda kendisi kaydetmiştir.

152 Sadâret vazifesi: 1209-1213/ 1794-1798. Bk. Ahmed Câvîd, Hadîkatü'l-vüzerâ Zeyli, İstanbul 1271, s. 47-49.
} 
günümüze ulaşıp ulaşmadığı bilinmiyorsa da, tercümesinin birçok yazma nüshaları vardır ${ }^{153}$. Hoca Neş'et'in tercümesi, Elif Memiş tarafından yüksek lisans tezi olarak çalışılmıştır ${ }^{154}$.

\section{Naîmullah Behrâiçî (ö. 1218/1803), Ma'mûlât-ı Mazhariyye.}

Hindistanlı meşhur Nakşbendî-Müceddidî şeyhi Mazhar Cân-1 Cânân'ın müridi olan Na'îmullah Behrâiçî tasavvuf âdâb1, zikir, teveccüh, râbıta, hatm-i Hâcegân, namaz, oruç gibi konularda Ma'mûlât-ı Mazhariyye isminde Farsça bir eser kaleme almıştır. Hindistan'da neşredilen eser (Kânpûr 1275/1858), Osmanlı son döneminde ismi bilinmeyen bir şahıs tarafinda Türkçeye tercüme edilmiştir ${ }^{155}$. Bu tercüme yüksek lisans tezi olarak çalışılmış ve yeni harflere de aktarılmıştır'156.

\section{Abdullah Dehlevî (ö. 1240/1824), Îzâhu't-tarîka.}

Hindistanlı Nakşbendî-Müceddidî şeyhlerinden Mazhar Cân-1 Cânân'ın mürid ve halifesi olup Gulâm Ali lakabiyla da anılan Abdullah Dehlevî’nin Îzâhu't-tarîka isimli Farsça eseri ${ }^{157}$, Osmanlı döneminde Mehmed Bahâeddin tarafindan Fevâid Tercümesi adıyla Türkçeye tercüme edilmiştir ${ }^{158}$.

\section{Ebû Sa'îd Fârûkî (ö. 1250/1835), Hidâyetü 't-tâlibîn}

Hindistanlı Nakşbendî-Müceddidî şeyhi Abdullah Dehlevî’nin mürid ve halifesi olan Ebû Sa'îd Fârûkî, Nakşbendî tarikatının seyr u sülük (tasavvufî eğitim) merhalelerini anlatan Hidâyetü't-tâlibîn isminde Farsça bir eser kaleme almıştır (nşr. Gulâm Mustafa Hân, Karaçi: İdâre-i Müceddidiyye, 1385/1965).

Eser, Osmanlı son döneminde Muhammed b. Veliyyüddin Hıfzî1 ${ }^{159}$ tarafın-

153 Seyyid Burhâneddin Muhammed Nakşbendî, Meslekü’l-envâr ve menba'u'l-esrâr (trc. Hoca Neş'et), Süleymaniye Ktp., Hacı Mahmud, nr. 2483, vr. 1b-54b; İstanbul Belediye Ktp., K-569; Süleymâniye Ktp., Hacı Mahmud Efendi, 2473 (64 varak).

154 Elif Memiş, Edirneli Süleymen Neş'et'in Meslekü'l-envâr ve menbau'l-esrâr Tercümesi (Metin ve İnceleme), Marmara Ün. Sosyal Bilimler Enstitüsü, 2019 (yüksek lisans tezi).

$155 \mathrm{Bu}$ tercümenin el yazma bir nüshasının fotokopisi kütüphanemizdedir.

156 Hatice Gargu, Mevlânâ Hâce Naîmullah Behrâyiçî̀nin Ma'mûlât-ı Mazhariyye İsimli Eserinin Türkçe Tercemesi'nin Transkripsiyon ve Tahlîli, Uludağ Üniversitesi Sosyal Bilimler Enstitüsü, YL tezi, Bursa 2015.

157 Îzâhu’t-tarîka, ayrıca Abdullah Dehlevî’nin mektupları arasında 90. mektup olarak da yayınlanmıştır. Bkz. Abdullah Dehlevî, Mekâtîb-i Şerîfe, İstanbul 1992, s. 134-160 (Farsça).

158 Abdullah Dehlevî, Fevâid Tercümesi, trc. Mehmed Bahâeddin, İstanbul Belediye Ktp., Osman ergin Yazmaları, nr. 870 (35 varak).

159 Bu mütercim (Muhammed Hifzî), eserin müellifi olan Ebû Sa'îd Fârûkî’nin oğlu Ahmed Sa'id Fârûkî'nin oğlu Abdürreşî̀d Müceddidî’nin müridi imiş. Bkz. Mehmed Tâhir, Osmanlı Müellifleri, c. 1, s. 184. 
dan 1253 (1837) senesinde Tercüme-i Hidâyetü't-tâlibîn adıyla Türkçeye tercüme ve neşredilmiştir (İstanbul 1299/1882).

\section{İmdâdullah Fârûkî Çiştî Thânevî (ö. 1329/1899), Ziyâül- kulûb, Risâle der Beyân-ı Vahdetü'l-Vücûd}

Ziyâü'l-kulûb: Hindistanlı Çiştî şeyhlerinden ${ }^{160}$ İmdâdullah Thânevî Muhâcir-i Mekkî'nin Ziyâü'l-kulûb isimli Farsça eseri, Osmanlı döneminde Mevlevî Es'ad Dede (ö. 1911) tarafından Türkçeye tercüme edilmiştir ${ }^{161}$. Bu tercümenin yazma nüshası Adnan Kaya tarafından yeni harflere çevrilerek Kalplerin Işı̆̆l: Ziyâu'l-kulûb Tercümesi adıyla neşredilmiştir ${ }^{162}$.

Risâle der Beyân-ı Vahdetü'l-vücûd: İmdâdullah Thânevî'nin Risâle der Beyân-l Vahdetü'l-vücûd isimli Farsça eseri de ${ }^{163}$ Ahmed Avni Konuk tarafindan Türkçeye tercüme edilmiştir ${ }^{164}$.

\section{Abdülkâdir Belhî (ö. 1923), Esrâru’t-tevhîd.}

Abdülkâdir Belhî Afganistan'da doğmuştur. Babası Süleyman Belhî Kunduzî'dir. 1855 'te akrabaları ile birlikte Afganistan'dan Anadolu'ya göç eden ve İstanbul Eyüp'te babasından sonra Murâd Buhârî Dergahı'nda şeyh olan Abdülkâdir Belhî’nin Esrâru't-tevhîd isimli Farsça manzum eseri, Mehmed Nâzım Paşa tarafından Türkçeye tercüme edilip neşr edilmiştir ${ }^{165}$.

\section{Sonuç}

İlim, kültür ve irfanı kıtalar ötesine taşıyan en önemli unsurlardan biri kitaplardır. İran, Afganistan, Tacikistan, Mâverâünnehr (Özbekistan) ve Hindistan'da yazılan birçok tasavvufî eser, Osmanlı döneminde Türkçeye tercüme edilmiştir. Miladî 11. Yüzyıldan 15. Yüzyıla kadar çoğunlukla İran coğrafyasında yazılan tasavvufî̀ eserler Türkçeye tercüme edilmiş iken, 15. Yüzyılda sonra Orta Asya,

160 Bu zâtın Çiştiyye dışında Nakşbendiyye ve Sühreverdiyye gibi tarikatlardan da teberrüken icâzeti vardı. 161 İstanbul Belediye Ktp., Osman Ergin Yzm., nr. 105 (65 varak); Konya Mevlânâ Müzesi Ktp., nr. 4521.

162 İmdâdullah Tehânevî, Kalplerin Işı̆̆̆ Ziyâu'l-kulûb Tercümesi (trc. Mehmed Es'ad Dede, hzr. Adnan Kaya), İstanbul: İnsan Yayınları, 2007.

163 Bombay 1300/1883; ayrıca Külliyyât-ı İmdâdiyye içinde, Kanpur ts.; Külliyyât-ı İmdâdiyye, Karaçi 1976, s. 218-223. 164 Konya Mevlana Müzesi Ktp., nr. 3649; İstanbul Belediye Ktp., O.E. Yzm., nr. 31; Süleymaniye Ktp., Tâhir Ağa Tekkesi, nr. 772, vr. 14-20.

165 Abdülkâdir Belhî, Esrâru 't-Tevhîd ve Tercümesi, İstanbul 1331/1913 (s. 1-18 Farsça, s. 19-28 Türkçe). Nihat Azamat, “Abdülkâdir-i Belhî”, Diyanet İslam Ansiklopedisi, İstanbul 1988, c. 1, s. 231-232. 
Afganistan ve Hindistan bölgesinde yaşayan Nakşbendî mensuplarının eserleri tercüme edilmeye başlanmıştır. Bunun iki temel sebebi vardır: Birincisi 15. Yüzyıldan itibaren Anadolu'da Nakşbendîler etkili bir şekilde yayılmışlar ve kendi tarîkatlarına ait eserleri tercüme etmeye daha fazla önem vermişlerdir. İkinci sebep, 15. Yüzyıldan sonra İran'da çok önemli ve İslam dünyasında ses getirecek eserler yazılamamıştır.

Öte yandan İran'da yazılan Bostan, Gülistân, Mantıku't-tayr ve Pend-i Attâr gibi eserler üzerine Türkçe birçok şerh yazılmıştır. Hattâ bu Türkçe şerhlerden bazıları çok değerli bulunmuş ve Farsçaya çevrilip yayınlanmıştır. Yani Farsçadan Türkçeye çevrilip şerh edilen eserler tekrar Farsçaya çevrilip asıl vatanında okunur hâle gelmiştir. Bu sayede ülkeler arasında kültür paylaşımı olmuş, İslam kültürüne önemli katkılar sağlanmıştır.

Hindistan'ın uzak bir kasabasında yazılan Farsça bir eserin Osmanlı döneminde Anadolu'da Türkçeye çevrilip bir Türk köyünde mum 1şı̆̆ında okunması, iletişim imkânlarının kısıtlı olduğu dönemlerde İslam dünyasının kültürel işbirliği adına muazzam bir faaliyet olmuştur.

$\mathrm{Bu}$ makâlede, Osmanlı döneminde Farsçadan Türkçeye tercüme edilen tasavvufî eserlerin önde gelenleri toplanıp bir araya getirilmiş, böylece konuya ilgi duyan kişilere ve araştırmacılara önemli bir kolaylık sağlanmıştır. Ayrıca makâlede,

a. Osmanlı döneminde hangi tasavvufî eserlerin Türkçeye tercüme edildiği,

b. Tercümelerin hangi coğrafyalardan (İran, Orta Asya, Hindistan vs.) yapıldığı,

c. 15. Yüzy1ldan sonra tercümeye konu olan eserlerin İran'dan ziyâde Orta Asya ve Hindistan'a kaymasının sebepleri gibi problemlerin cevabı aranmıştır.

Söz konusu eserlerden henüz yazma hâlinde olanların ilmî usullerle yeni harflere çevrilerek yayınlanması edebiyat, tasavvuf ve kültür dünyamıza önemli bir katkı olacaktır. 


\section{Kaynakça}

Ahrâr, Ubeydullâh, Resâil-i Hâce Ahrâr (nşr. Ârif Nevşâhî), Herat 2015.

Akkuş, Muzaffer, Elvan-ı Şirazi'nin Gülşen-i Raz'ı, Ankara 2002.

Akpınar, İsa, “XVI. Asır Şairlerinden Emîrî’nin Mergûbu'l-kulûb Tercümesi”, Türk Kültürü ve Hacı Bektaş Veli Araştırma Dergisi, sy. 89 (Bahar 2019), s. 147-167.

Alkan, Ercan, "Hacı Bayram-1 Velî’nin İsteğiyle Yapılan Bir Tercüme: İnce Bedreddin ve Tercüme-i Lema'ât'1”, Tasavvuf: İlmî ve Akademik Araştırma Dergisi, sy. 31 (2013), s. $57-73$.

Alparslan, Ali, “Abdülvehhâb es-Sâbûnî”, Diyanet İslam Ansiklopedisi, İstanbul 1988, c. 1, s. 286-287.

Ankaravî, İsmail Rusûhî, Mesnevî Şerhi: Mecmûatü'l-letâif ve ma'mûretü'l-ma'ârif, Misır 1221/1806.

Aruçi, Muhammed, "Sûdî Bosnevî”, Diyanet İslam Ansiklopedisi, İstanbul 2009, c. 37, s. 466.

Atâî, Nev'îzâde, Hadâiku'l-hakâik, İstanbul 1268/1852.

Averbek, Güler Doğan, “Fedâyî Mehmed Dede Mantık-1 Esrâr Adlı Manzûm Mantıku’t-tayr Tercümesi ve Otograf Nüshası”, Uluslararası Türkçe Edebiyat Kültür Eğitim Dergisi, c. 6 , sy. 3 (2017), s. 1490-1506.

Azamat, Nihat, "Yeni Bir Ahmedi ve İki Eseri: Yûsuf u Zelîha, Esrarnâme Tercümesi”, Osmanlı Araştırmaları, sy. VII-VIII (1988), s. 347-364.

Bağdatlı İsmail Paşa, Hediyyetü'l-ârifin, Beyrut ts.,

Bayak, Cemal, "Sehâbî”, Diyanet İslam Ansiklopedisi, İstanbul 2009, c. 36, s. 309-310.

Belhî, Abdülkâdir, Esrâru't-Tevhîd ve Tercümesi, İstanbul 1331/1913.

Bosnevî, Sûdî, Gülistân Şerhi (nşr. Ozan Yılmaz), İstanbul: Çamlıca Basım Yayın, 2012.

Buhârî, Salâh b. Mubârek, Enîsü t-tâlibîn ve uddetü 's-sâlikîn (nşr. Halil İbrahim sarığlu), Tahran 1371 hş./1992.

Câmî, Abdurrahman, Levâmi' Tercümesi (trc. Tâhirü'l-Mevlevî), Marmara Ün. İlahiyat Fakültesi Ktp., Yazmalar, nr. 21, s. 64-205 (varaklar sayfa usulü numaralandırılmış).

Câmî, Molla, Şerh-i Rubâiyyât (trc. Tâhiru'l-Mevlevî, hzr. Abdurrahman Acer), İstanbul: Litera Yayınc1lik, 2014.

Ceyhan, Semih, "Mesnevî”, Diyanet İslam Ansiklopedisi, İstanbul 2004, c. 29, s. 325-334.

Ceylan, Kübra - Şule Bayraktar, "Hâce Abdullah el-Ensârî el-Herevî’nin Münâzara-i Dil ü Cân Adlı Risâlesi ve Türkçe Tercümesi”, Tasavvuf: İlmî ve Akademik Araştırma Dergisi, sy. 32 (2013), s. 203-220. 
Çal, Ahmet, “Kasım b. Mahmud Karahisarî'nin İrşadü'l-mürid ile'l-murâd fî̀ tercemeti Mirsâdi'l-ibâd Adlı Eseri”, Turkish Studies, c. 10-12 (2015), s. 233-248.

Çerhî, Ya‘kûb, Tercüme-i Risâle-i Ünsiyye (trc. La'lîzâde Abdülbâkî), Süleymaniye Ktp., Pertev Paşa, nr. 636, vr. 227b-242b.

Düzen, İbrahim, “Azîz Nesefî”, Diyanet İslam Ansiklopedisi, İstanbul 1991, c. 4, s. 344-346.

Emîrî, Slfâtü'l-âşıkîn, İsveç, Uppsala Üniversitesi Ktp., O Vet 63, vr. 235b-290b.

Erdebîlî, İbn-i Bezzâz, Safvetü 's-safâ (nşr. Gulâm Rizâ Tabâtabâî Mecd), Tebrîz 1373 hş./1994.

Gurâbzâde Ahmed, Zübedü âsâri'l-Mevâhib ve'l-Envâr, İstanbul 1292-1294.

Güleç, İsmail - Güler Doğan Averbek, “Gölgede Kalmış Bir Şairin Bilinmeyen Üç Tercümesi”, Dil ve Edebiyat Araştırmalarl, sy. 18 (Güz 2018), s. 247-264.

Güleç, İsmail, "Sürûrî, Muslihuddin Mustafa”, Diyanet İslam Ansiklopedisi, İstanbul 2010, c. 38, s. 170-172.

Gülşenî, Muhyî, Reşehât-ı Muhŷ̂ (nşr. Mustafa Koç- Eyyüp Tanrıverdi), İstanbul: Türkiye Yazma Eserler Kurumu Başkanlığı Yayınları, 2014.

Günel, Fuat, "Üsküdârî, İsâmüddin”, Diyanet İslam Ansiklopedisi, İstanbul 2016, c. Ek-2, s. 640-641. https://islamansiklopedisi.org.tr/uskudari-isamuddin

Hânkâhî, Ebû Nasr, Güzîde der Ahlâk ve Tasavvuf (nşr. Îrec Efşâr), Tahran 1347 hş. /1966.

Hemedânî, Abdülvehhâb, Sevâkıbu'l-menâkıb-ı Evliyâullâh (nşr. Ârif Nevşâhî), Tahran: Merkez-i Pejûheşî-yi Mîrâs-1 Mektûb, 1390 hş./2011.

Hocazâde Ahmed Hilmî, "Hoca Azîzân Ali Râmîtenî Hazretlerinin Risâle-i Şerîfesi Tercümesi”, Cerîde-i Sûfiyye, sy. 60 (1331/1913), s. 130-131; sy. 61 (1331/1913), s. 143-145.

İnan, Mehmet Emin, XVI. Asır Şâirleriden Za'îfì ve Bâğ-ı Behişt Mesnevîsi, Erciyes Üniversitesi Sosyal Bilimler Enstitüsü, YL tezi, Kayseri 1998.

Kara, Mustafa, "Hocazâde Ahmed Hilmi”, Diyânet İslam Ansiklopedisi, İstanbul 1998, c. 18, s. 207.

Kâşgarî, Abdullah Nidâî, Risâle-i Hafiyye (trc. Edirne Kadısı Mustafa İsâmeddin), İstanbul Belediye Ktp., O.E.Yzm., nr. 919, vr. 1b-50b.

Kâtib Çelebi, Keşfu'z-zunûn, Beyrut ts.,

Kemâl Ahmed Dede, Tercüme-i Menâkıb-ı Mevlânâ, Süleymaniye Ktp., Hâlet Efendi Mülhak1, nr. 82 (158 varak).

Konevî, Sadreddin, Tebsıratü'l-mübtedî tezkiretü'l-müntehî, trc. Ahmed Remzî el-Mevlevî, İstanbul Belediye Ktp., Osman Ergin Yazmaları, nr. 327 (56 varak).

Mahmûd b. Osmân, Firdevsü'l-mürşidiyye fì esrâri'ṣ-șamediyye (nşr. Îrec Efşâr, Tahran 1358 hş./1979).

Mecdî Mehmed, Hadâiku'ş-Şakâik, İstanbul 1269/1853. 
Mehmed İzzet Paşa, Gonca-i Bostân, İstanbul, Millet Kütüphanesi, Ali Emîrî Manzûm, nr. 1203 (160 varak).

Mehmed Tâhir, Osmanlı Müellifleri, İstanbul 1333/1915.

Memiş, Abdurrahman, Hâlid-i Bağdâdî ve Anadolu'da Hâlidîlik, İstanbul 2000.

Menâkıb-ı Evhadüddîn Hâmid b. Ebi'l-Fahr Kirmânî (nşr. Bedîuzzamân Fürûzânfer), Tahran 1347 hş./1969.

Mercan, İ. Hakkı, Menâkıbnâme-i Şeyh Evhadeddin Kirmânî (YL tezi), Kayseri 1990.

Musal1, Namiq, "Şeyh Safi Velâyetnâmesi: Tahkiki ve Transkripsiyonu”, Türk Kültürü ve Hacı Bektaş Veli Araştırma Dergisi, sy. 84 (2017), s. 166-168.

Münzevî, Ahmed, Fihrist-i Müşterek, İslâmâbâd-Lahor 1988.

Nakşbendî, Seyyid Burhâneddin Muhammed, Meslekü'l-envâr ve menba 'u'l-esrâr (trc. Hoca Neş’et), Süleymaniye Ktp., Hacı Mahmud, nr. 2483, vr. 1b-54b.

Namoğlu, Elif, Ebû Abdullah Muhammed es-Semerkandî'nin Muhtasaru'l-velâye Adlı Eseri (Metin-İnceleme), İstanbul Üniversitesi Sosyal Bilimler Enstitüsü, YL tezi, 2012.

Nevşâhî, Ârif, "Risâle-i Vâlidiyye-i Ubeydullâh-i Ahrâr-i Semerkandî", Tahkîkât-ı İslâmî, IX/1-2 (1373/1994), s. 65-77.

Nevşâhî, Ârif, “Sevâkıbu'l-menâkıb-1 Evliyâullah: Mevlânâ ve Mevlevîlik Hakkında Unutulmuş Bir Kaynak", (trc. Necdet Tosun), Tasavvuf: İlmî ve Akademik Araştırma Dergisi, sy. 14 (2005), s. 697-707.

Nizam, Betül Sinan, Kemâl Ahmed Dede's Verse Narrative Tercüme-i Menâkıb-ı Mevlânâ (A Verse Version in the Menâkıbü'l-Ârifin Tradition), Cambridge, Harvard Üniversitesi, 2010.

Nizami, Khaliq Ahmad, "Hüseynî Sâdât el-Gûrî”, Diyanet İslam Ansiklopedisi, İstanbul 1999, c. 19, s. 24 .

Öngören, Reşat, "Konuk, Ahmet Avni”, Diyanet İslam Ansiklopedisi, İstanbul 2002, c. 26, s. 180-182.

Özkan, Mustafa, "Edirneli Nazmî”, Diyanet İslam Ansiklopedisi, İstanbul 1994, c. 10, s. 450451.

Öztürk, Şeyda, “Şem'̂̂”, Diyanet İslam Ansiklopedisi, İstanbul 2010, c. 38, s. 503-504.

Semerkandî, Muhammed b. Burhâneddin, Silsiletü 'l-ârifîn ve tezkiretü's-sıddîkîn (nr. İhsânullah Şükrullâhî), Tahran: Kitâbhâne Mûze ve Merkez-i Esnâd-1 Meclis-i Şûrâ-y1 İslâmî, 1388 hş./2009.

Sevgi, H. Ahmet, “Mantıku't-tayr”, Diyanet İslam Ansiklopedisi, İstanbul 2003, c. 28, s. 29-30.

Sipehsâlâr, Ferîdûn, Menâkıb-ı Hazret-i Mevlânâ Celâleddin-i Rûmî (trc. Ahmed Avni Konuk), İstanbul 1331. 
Sunguroğlu, İsmet, Harput Yollarında, İstanbul 1958.

Şebüsterî, Mahmûd, Tercüme-i Gülşen-i Râz, trc. Elvân-1 Şîrâzî, İstanbul Belediye Ktp., Osman Ergin Yazmaları, nr. 863 (106 varak).

Şem’î, Şerh-i Bostân-1 Şeyh Sa'dî, Beyazıt Devlet Ktp., Veliyyüddin bölümü, nr. 3666 (238 varak).

Şem'î, Şerh-i Mantıku't-tayr (hzr. Muhittin Turan), İstanbul: Kesit Yayınları, 2015.

Tehânevî, İmdâdullah , Külliyyât-ı İmdâdiyye, Karaçi 1976.

Tokmak, A. Naci, "Hâcû-yi Kirmânî", Diyanet İslam Ansiklopedisi, İstanbul 1996, c. 14, s. 520-521.

Tosun, Necdet, Bahâeddin Nakşbend: Hayatı Görüşleri Tarîkatı (XII-XVII. Asırlar), İstanbul 2002.

Tosun, Necdet, Türkistan Dervişlerinden Yâdigâr: Orta Asya Türkçesiyle Yazılmış Tasavvufí Eserler, İstanbul 2011.

Tosyavî, Abdülmecîd, el-Lemehât fî tercemeti'l-Leme'ât, Kastamonu İl Halk Ktp., nr. 36, vr. 231b-246b.

Türkoğlu, Serkan, “Türk Edebiyatında Pendnâme-i Attâr'ın Manzum Tercümeleri ve Seyyid Ali Rızâ'nın Riyâzü'r-Rızâ'sı”, Atatürk Üniversitesi Sosyal Bilimler Enstitüsü Dergisi,,sy. 22 (Nisan 2018), s. 671-692.

Vassâf, Hüseyin, Sefine-i Evliyâ (nşr. Ali Yılmaz- Mehmet Akkuş), İstanbul 2006.

Yârahmedî, Sîmâ - Gulâm Rızâ Dâdhâh, "Mergûbu'l-kulûb”, Ittılâ'ât-ı Hikmet ve Ma'rifet, sy. 8 (1386 hş./2007), s. 50-55.

Yaşaroğlu, M. Kâmil, “Mûsâ İznikî”, Diyanet İslam Ansiklopedisi, İstanbul 2006, c. 31, s. 218 219.

Yazar, Sadık, "Gazzâlî’nin XIII-XIX. Yüzyıllar Arasında Batı Türkçesinde Tercüme Edilen Eserleri”, Divan: Disiplinlerarası Çalı̧̧malar Dergisi, c. 16, sy. 31 (2011), s. 88-91.

Yazar, Sadık, "XVI. Yüzyıl Şâirlerinden Üsküdarlı Aşkî'nin Eserleri Hakkında Yeni Tespitler”, Türkiyat Mecmuast, c. 21 (2011), s. 375-393.

Yazar, Sadık, Anadolu Sahası Klâsik Türk Edebiyatında Tercüme ve Şerh Geleneği, İstanbul Üniversitesi Sosyal Bilimler Enstitüsü, Dr. Tezi, 2011.

Yazıcı, Tahsin - Süleyman Uludağ, "Herevî, Hâce Abdullah" md., Diyânet İslam Ansiklopedisi, İstanbul 1998, c. 17, s. 225.

Yazıcı, Tahsin, “Menâkıbü'l-ârifîn”, Diyanet İslam Ansiklopedisi, İstanbul 2004, c. 29, s. 114-115.

Yazıcıŏlu, Mustafa Said, "Hızır Bey”, Diyanet İslam Ansiklopedisi, İstanbul 1998, c. 17, s. 414. 